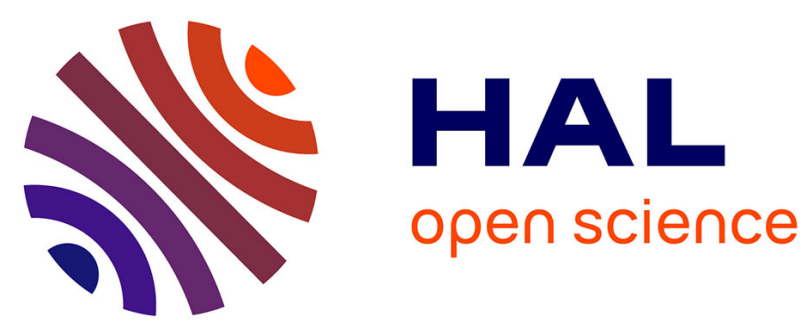

\title{
The scale of effect depends on operational definition of forest cover-evidence from terrestrial mammals of the Brazilian savanna
}

Christophe Amiot, Cyntia Cavalcante Santos, Damien Arvor, Beatriz Bellón, Hervé Fritz, Clément Harmange, Jeffrey D D Holland, Isabel Melo, Jean-Paul Metzger, Pierre-Cyril Renaud, et al.

\section{To cite this version:}

Christophe Amiot, Cyntia Cavalcante Santos, Damien Arvor, Beatriz Bellón, Hervé Fritz, et al.. The scale of effect depends on operational definition of forest cover-evidence from terrestrial mammals of the Brazilian savanna. Landscape Ecology, 2021, 36 (4), pp.973-987. 10.1007/s10980-021-01196-9 . halshs-03131932

\author{
HAL Id: halshs-03131932 \\ https://shs.hal.science/halshs-03131932
}

Submitted on 21 Oct 2021

HAL is a multi-disciplinary open access archive for the deposit and dissemination of scientific research documents, whether they are published or not. The documents may come from teaching and research institutions in France or abroad, or from public or private research centers.
L'archive ouverte pluridisciplinaire HAL, est destinée au dépôt et à la diffusion de documents scientifiques de niveau recherche, publiés ou non, émanant des établissements d'enseignement et de recherche français ou étrangers, des laboratoires publics ou privés. 


\section{The scale of effect depends on forest definition - evidence from terrestrial \\ 2 mammals of the Brazilian savanna}

3

$\underline{\text { Amiot }}$ Christophe ${ }^{\mathrm{a} g}, \underline{\text { Santos }}$ Cavalcante Cyntia ${ }^{\mathrm{a}} \mathrm{j}, \underline{\text { Arvor Damien }}{ }^{\mathrm{b}}, \underline{\text { Bellón Beatriz }}{ }^{\mathrm{a} \mathrm{k}}, \underline{\text { Fritz }}$ Hervéc $^{\mathrm{g} i}$, $\underline{\text { Harmange Clément }}{ }^{\mathrm{ag}}, \underline{\text { Holland Jeffrey D. }}{ }^{\mathrm{d}}, \underline{\text { Melo }}$ Isabel $^{\mathrm{e}}$, $\underline{\text { Metzger Jean Paul }}{ }^{\mathrm{f}}$, $\underline{\text { Renaud }}$ Pierre-Cyril $^{\text {a g }}$, Roque Fabio de Oliveira ${ }^{\text {e }}$, $\underline{\text { Souza }}$ Franco Leandro ${ }^{\mathrm{e}}, \underline{\text { Pays }}$ Olivier ${ }^{\text {g }}{ }^{*}$

a LETG-Angers, UMR 6554 CNRS, Université d'Angers, 49045 Angers, France.

b LETG-Rennes, UMR 6554 CNRS, Université de Rennes 2, 35043 Rennes, France

${ }^{\mathrm{c}}$ CNRS, Université Lyon, Université Lyon 1, Laboratoire de Biométrie et Biologie Evolutive UMR 5558, F-69622 Villeurbanne, France.

${ }^{\mathrm{d}}$ Department of Entomology, Purdue University, West Lafayette, Indiana, 47907 USA.

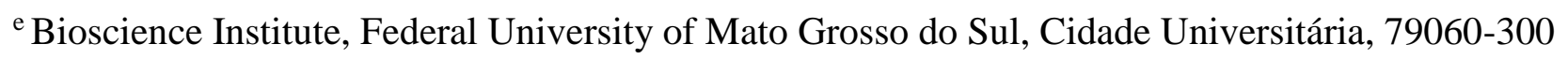

Campo Grande, MS, Brazil

${ }^{\mathrm{f}}$ Universidade de São Paulo, Departamento de Ecologia, São Paulo, SP, Brazil

${ }^{\mathrm{g}}$ REHABS International Research Laboratory, CNRS-Université Lyon 1-Nelson Mandela

University, George Campus, Madiba drive 6531 George, South Africa.

${ }^{\mathrm{h}}$ Centre for Tropical Environmental and Sustainability Science (TESS) and College of Science and Engineering, James Cook University, Cairns, Qld, Australia

${ }^{\text {i }}$ Sustainability Research Unit, Nelson Mandela University, Port Elizabeth, South Africa

${ }^{j}$ Wetlands International - Brazil, Campo Grande, Mato Grosso do Sul, Brazil

${ }^{\mathrm{k}}$ Department of Environmental Science, Rhodes University, Makhanda 6140, South Africa

* Corresponding author: Olivier Pays, LETG-Angers, UMR 6554 CNRS, Université d'Angers, Campus Belle Beille, 2 Bd Lavoisier, 49045 Angers, France.

e-mail address: olivier.pays @ univ-angers.fr (O. Pays), phone: +33 (0) 241735261.

Author ORCID:

Amiot Christophe 0000-0002-4788-0928

Santos Cavalante Cyntia 0000-0002-8207-9263

Arvor Damien 0000-0002-3017-9625 
32 Bellón Beatriz 0000-0002-9620-6200

33 Fritz Hervé 0000-0002-7106-3661

34 Harmange Clément 0000-0001-5207-021X

35 Holland Jeffrey D. 0000-0003-4889-6363

36 Metzger Jean Paul 0000-0002-0087-5240

37 Renaud Pierre-Cyril 0000-0003-1776-4923

38 Roque Fabio de Oliveira 0000-0001-5635-0622

39 Souza Franco Leandro 0000-0002-7041-4036

40 Pays Olivier 0000-0001-8268-1804

41

42 Keywords

43 Scale of response; Tree cover; Spatial scale; Multi-scale model; Mammal; Herbivore; Brazil 44 45 


\section{Abstract}

47 Context The underlying mechanisms determining the scale at which species interact with their

48 environment are still poorly known.

49 Objective We investigated the spatial extent at which landscape structure affects the occurrence of

50 four species of terrestrial mammal herbivores in the Brazilian savannas and tested whether those

51 scales could be explained by species ecological traits and habitat definition.

52 Methods Using maps of forest cover, camera trapping and occupancy modelling, we determined the

53 relations between three landscape metrics (percentage of forest cover, patch density and edge

54 density) and the occurrence of four species. To determine the optimal scale of effect for each

55 species, we computed landscape metrics at different spatial extents (from 0.5 to $10 \mathrm{~km}$ radius) from

56 camera trap locations and for three forest maps, considering different definitions of what is a

57 "forest" (minimum of tree cover of 25,50 or $75 \%$ per pixel).

58 Results The occupancy models revealed scales of effect of 0.5 to $2 \mathrm{~km}$, and those scales overlapped

59 highly among species. However, the strength of the effect depends highly on how forest is defined,

60 being stronger when forest was defined with greater tree cover, particularly for forest-dwelling

61 species.

62 Conclusions Besides biological traits, the way habitat is defined shapes our ability to detect scale of

63 effects. Thus, if we want to properly identify scales of effect for multiple species, it is necessary not

64 only to adopt a multi-scale approach, but also to use multiple definitions of habitat, considering

65 particularities of how each species interact with their environment. 


\section{Introduction}

Identifying the spatial scale at which species respond to landscape structure, or the scale of effect

(Jackson and Fahrig 2012) has become an important scientific challenge when investigating species-environment relationships (Fahrig et al. 2011; Redon et al. 2014; Miguet et al. 2016, 2017).

As species might respond to a specific landscape attribute at a particular scale, studies have pointed out the importance to consider multiple spatial scales when investigating the effects of habitat change on species (Levin 1992). This is particularly relevant in the understanding of mechanisms underlying the erosion of biodiversity, especially the mechanisms for which human activities shape land use and land cover changes (Newbold et al. 2015; Püttker et al. 2020). Knowing the scale at which species respond to landscapes should help decision-makers in designing management plan to maintain and restore biodiversity and their habitats (Haines-Young 2009).

From an ecological standpoint, optimal spatial extents are mainly determined by the scale at which ecological processes are expected to operate for the studied organisms. Huais (2018) argued that ecologists do not usually know a priori which are those optimal spatial extents, mainly due to a lack of a full understanding of the underlying biological processes (Jackson and Fahrig 2015). However, several studies have clarified the link between spatial scale and the ecological responses of species under investigation (Levin 1992; Saab 1999; Crawley and Harral 2001; Chase and Leibold 2002; Leibold et al. 2004; Rahbek 2005; Gabriel et al. 2010; Delsol et al. 2018). For instance, the effect of spatial extent has been particularly investigated in habitat selection (Fortin et al. 2008) and animal movement (Fryxell et al. 2008). For large mammal herbivores, Mayor et al. (2009) have reported spatial scales at which ecological and behavioural mechanisms underlying habitat selection should be investigated. Analysing the activities of animals at fine scales (i.e., $1-$ $100 \mathrm{~m}$ ) allows to investigate bite, feeding site and patch selection, while studies at local scales (100 $\mathrm{m}-10 \mathrm{~km}$ ) allow the understanding of habitat selection and home range, and finally, research at broader, regional scales $(>10 \mathrm{~km})$ are relevant for migration and (meta)population dynamics comprehension (Johnson 1980; Danell et al. 2006).

Without knowing a priori what is the appropriate scale of study, landscape ecologists commonly assess landscape variables at multiple scales to select the scale that yields the best species-landscape relationship (e.g. Brennan et al. 2002; Holland et al. 2004; Holland and Yang 2016; Melo et al. 2017; Huais 2018). Different methods or statistical analyses have been proposed in the literature to test for the effect of landscape features on species attributes (e.g., richness, abundance, composition) at different spatial scales and to extract their goodness of fit through an appropriate criterion index (e.g., correlation and determination coefficients or AIC). Spatial scales are usually tested by varying spatial extent (e.g., the size of a buffer zone) over which the habitat 
102 predictor variable (i.e., a landscape metric) is measured. The scale of effect is commonly derived by

103 plotting the spatial scale (e.g., buffer size) against goodness of fit. This is sometimes challenging

104 because there is a common lack of knowledge on 1) the suitable landscape metrics to investigate the ecological processes, and 2) the appropriate grain extent at which their relationships should be assessed.

Biological/ecological traits of species including for instance body size, dispersal distance, home range and habitat specialisation may affect the scale of effect (Miguet et al 2016). Those traits are particularly relevant when they are indicators of animal mobility, a key biological feature which determines the relationship between species attributes and their surrounding space (Bowman et al. 2002). Although the empirical studies are not all in agreement, we might expect that the scale of effect would be larger for larger-bodied species because they are more mobile with higher dispersal

113 distance and home range than smaller-bodied species (Jackson and Fahrig 2012; Miguet et al 2016).

114 Thus, when investigating the effect of landscape features on species occurrence, a general guideline

115 for empirical studies is to consider a radius of a landscape to be $4-9$ times the median dispersal 116 distance or $0.3-0.5$ times the maximum dispersal distance of a species. Thornton and Fletcher 117 (2014) in their meta-analysis on birds reported a positive correlation between body size and the 118 spatial scale at which species responded to landscape variables. Finally, the scale of effect may 119 differ between specialist and generalist species of similar body-size although this literature is sparse and not in agreement on whether habitat specialists would exhibit a larger or smaller scale of effect (Boscolo and Metzger 2009; Chaplin-Kramer et al. 2013). Comparisons of habitat generalists and specialists have the added difficulty in consistently defining habitat for the different groups. Landscape features, related to both land use and land cover composition and spatial configuration, could also affect the scale of effect. Particularly, the type of maps of land use and land cover that are used as an input to derive patch-based landscape metrics may influence the assessments of scale of effect. This issue is especially relevant in tropical areas dominated by vegetation gradients (ranging from herbaceous layers with sparse trees to shrubland and forested areas, including degraded forests or regenerating forests) where the definition of landscape units can be arbitrary, and low thematic resolution in land cover maps (e.g., a small number of classes) may lead to an overly simplified representation of reality that may not adequately represent how species perceive their environment (Comber et al. 2005; Rocchini et al. 2013). Moreover, the definition of what is a "forest," for instance, is vague, ambiguous and highly subjective (Bennett 2002) where gradients in tree cover exist. Indeed, hundreds of different definitions of "forest" coexist (Chazdon et al. 2016), and obviously, none of these use a species perspective. While Hansen et al. (2010) used

$13525 \%$ of tree cover to map forest cover, Defries et al. (2001) defined forest cover as greater than $60 \%$ tree cover. Although using different percent tree cover would thus select different amount of 
canopy, it could also affect the type of vegetation that would be considered. In tropical and subtropical zones of Africa, Australia and South America, Hirota et al. (2011) reported that percent tree cover in savannas was about $20 \%$ and contrasted with $80 \%$ in forested areas. While mammal species might respond differently to forest cover (Royo and Carson 2005; Young et al. 2013; Chamaillé-Jammes et al. 2016; Ferreguetti et al. 2017; Zimbres et al. 2018), the question whether the percent tree cover used to map forest cover affects the scale of effect of landscape metrics on the occurrence of species has never been studied. This might be critical when modelling the presence of forest dwelling species in complex mosaic of vegetation types such as in Brazil's Cerrado including forests, savannas and grasslands (Bonanomi et al. 2019).

The aim of this study is to investigate the scale of effect in four common species of terrestrial mammal herbivores, the Azara's agouti Dasyprocta azarae, the collared peccary Pecari tajacu, the brown brocket deer Mazama gouazoubira, and the south American tapir Tapirus terrestris, using camera traps in the Brazilian Cerrado. First, we studied how the occurrence of those species responded to three landscape metrics commonly used to describe landscape composition (FC: percent of forest cover) and configuration (PD: patch density and ED: edge density) (Lidicker 1999; Bastian et al. 2006; Bennett et al. 2006; Lu et al. 2013; Lowicki 2017). These metrics have also been useful to explain mammal community distribution in Brazil (Mares et al. 1986; Arévalo-Sandi et al. 2018; Bovendorp et al. 2019; Püttker et al. 2020). Second, we investigated whether the definition of forest cover (i.e. 25,50 , or $75 \%$ of tree cover) affected the detection of scale of effect of the landscape features on the occurrence of species. Finally, as the four studied species differ in their body-size, dispersal and home range and forest specialisation (Table 1), we investigated whether the scale of effect varied among species with different biological/ecological traits.

We ran occupancy models for each species at 8 spatial extents from 0.5 to $10 \mathrm{~km}$ using 3 different maps of forest cover. We extracted the Akaike Information Criterion (AIC) for each model and examined whether species exhibited scale of effects. We hypothesized that mobility largely determines the relationship between landscape features and occurrence of the studied species. We therefore predicted that larger species with higher dispersal range and home range would exhibit a larger scale of effect than smaller species. In this context, the scale of effect of the South American tapir should be larger than the brown brocket deer and the collared peccary, with the smallest scale of effect in the Azara's agouti. Regarding forest definition (that shaped both land use and land cover composition and spatial configuration), we predicted a stronger or clearer scale of effect in the two forest-dwelling species, the Azara's agouti and collared peccary, when considering high tree cover (e.g., $75 \%)$ compared to medium-low tree cover $(50-25 \%)$. 


\section{Methodology}

174 Study site

175 The Bodoquena Plateau region $\left(20^{\circ} 25^{\prime} 29.28^{\prime \prime}\right.$ to $21^{\circ} 44^{\prime} 19.72^{\prime \prime} \mathrm{S}$ and $56^{\circ} 52^{\prime} 24.46^{\prime \prime} 56^{\circ}$ to $17^{\prime} 23.36^{\prime \prime}$

$176 \mathrm{~W}$ ) is located in the state of Mato Grosso do Sul, Brazil (Fig. 1a). It is characterized by a mountain 177 chain (altitude $450-800 \mathrm{~m}$ ) with a tropical climate (annual temperature varies between 20 and $17822^{\circ} \mathrm{C}$ and rainfall between 1300 and $1700 \mathrm{~mm}$ ). The study area is within the range of the Cerrado 179 biome (Brazilian savanna) in the region inside and around the Serra da Bodoquena National Park 180 (SBNP). The vegetation comprises a mix of alluvial semi-deciduous and submontane deciduous 181 forest (dry forest), wetlands, regenerating areas and agriculture including pastures and crops 182 (Oliveira and Marquis 2002; Klink and Machado 2005). SBNP represented an important protected area due to acting as an ecological corridor of biodiversity and by maintaining remnants of Atlantic Forest in the area. During the last decades, Cerrado has been experiencing a rapid agricultural expansion (Rausch et al. 2019), leading to fragmentation (Strassburg et al. 2017).

Forest cover, landscape metrics and spatial extent

Landscape metrics were computed using forest maps derived from the Global Forest Change project's products (Hansen et al. 2013). We used the "2000 percent tree cover" (TC) product, which corresponds to the proportion of trees per pixel, i.e. the canopy closure for all vegetation taller than $5 \mathrm{~m}$ in height. This global product is derived from the analysis of time series of Landsat images with a $30 \mathrm{~m}$ spatial resolution. We additionally used the "Forest loss year" product from the Global Forest Change project to remove all deforested areas between 2001 and 2017 (year of field collection; see below) from the forest class in the TC, i.e., TC was set to 0 for deforested areas. Based on this updated TC map, we then produced three forest maps for 2017 applying three thresholds of percent tree cover (25, 50, and 75\%) (Fig. 2).

Each of the three forest maps was then used to derive three landscape metrics: one metric of

198 landscape composition, forest cover (FC), and two additional metrics of landscape configuration,

199 patch density (PD) and the edge density (ED). FC is the proportion of pixels classified as forest in a

200 given area. PD measures the number of forest patches per $\mathrm{km}^{2}$ and ED is the total length of all

201 edges of forest patches divided by the buffer area. These three metrics were calculated using the

202 ClassStat function from the SDMTools package (VanDerWal et al. 2014) in R 3.6.2 (R Development

203 Core Team 2019). Although a large range of landscape metrics could have been explored, we

204 limited this to three variables in our study as (1) they are commonly used in the literature and (2)

205 they allowed an assessment of forest cover and fragmentation in the Cerrado in 2017 when we 
collected data in the field (Bonanomi et al. 2019). We checked that these three metrics were not significantly correlated.

We calculated ED, PD and FC at different scales, here considered as radii from the sampled areas (i.e. buffer radius of 500, 750, 1000, 1500, 2000, 3000, 5000 and $10000 \mathrm{~m}$ ). The range of spatial extents allowed the investigation of local and dispersal movements of species (Miguet et al. 2016) and have been used to explain habitat selection in terrestrial herbivorous mammals (Johnson 1980; Danell et al. 2006). We chose to exclude two smaller buffer sizes, 100 and $250 \mathrm{~m}$, as the small number of pixels from Landsat images (30 m spatial resolution) did not provide enough information to assess accurately PD, ED and FC (Strahler et al. 1986; Woodcock et al. 1987).

Finally, landscape variables showed scaling relations suggesting that they could be predicted over a wide range of spatial extents in our study area and remained quite constant beyond a buffer radius of $3 \mathrm{~km}$ (Electronic Appendices Table S1 and Fig. S1)

\section{Data from mammal species}

We deployed a set of 193 camera traps (Reconyx-hyperfire HC500 and Bushnel-trophy Cam HD) in a gradient of forest cover loss in the study area (Fig. 1b). Each camera trap was in the same location on two different periods of 20 consecutive days between May 2016 and December 2017. They were positioned $40 \mathrm{~cm}$ above the ground on the nearest tree of a computer-generated random point with a $10^{\circ}$ inclination towards the ground. To increase detection of animal movement and maximise identification of species, frame rate interval was set up at 3 seconds with 3 pictures per event. At the end of the sampling period, SD cards were extracted and analysed visually using Wild.ID (TEAM Network 2019). Each sampled picture was checked by two observers to reduce misidentification. In this study, we focused on four species of terrestrial mammals typical from Cerrado: Azara's agouti, collared peccary, brown brocket and South American tapir. Their ecological traits including body size, home range, habitat use, diet and dispersal distance are presented in Table 1.

\section{Occupancy models}

Creating large buffers around the locations of the 193 camera traps led to spatial overlaps and thus pseudoreplication. To tackle this issue, we used the Focus program (Holland et al. 2004) to conduct a plot-buffer related sampling using 10000 iterations on the 193 camera trap locations to select a set of spatially independent locations. Based on the retrials, Focus-2.0 randomly selected one combination of 57 independent locations allowing to increase buffer size up to $2 \mathrm{~km}$ (Fig. 1b). As the aim of our study was to understand the response of the occurrence of mammal species to the landscape metrics at wide range of different scales, we chose to use this combination to investigate scaling relations beyond $2 \mathrm{~km}$, i.e. 3,5 and $10 \mathrm{~km}$ although some minimal overlapping existed 
241 between several neighbouring buffers. Indeed, beyond $2 \mathrm{~km}$, Focus- 2.0 would have reduced the set 242 of combinations to 30 camera traps for which occupancy models failed to converge. Thus, we kept 243 the set of 57 selected locations and we then assessed each landscape metric described above at each buffer size and run occupancy models.

To investigate the effect of the landscape features (measured for the 8 buffer sizes and 3

246 percent threshold of tree cover) on the occurrence of the four mammal species, we run occupancy models using the unmarked $\mathrm{R}$ package (Fiske and Chandler 2011). For each of the 57 camera traps and focal species, we implemented a data set of 40 sampled days in which we indicated when the studied species was detected (coded as 1) vs. non-detected (coded as 0). Then, from the 40 sampled days, we built a matrix of 8 sampling occasions of 5 consecutive days each (as in Niedballa et al. 2015). Following this method, 13 camera traps (i.e., 23\%) have detected the presence of Azara's agouti, 15 (26\%) of collared peccary, 13 (23\%) of brown brocket deer and 25 (44\%) of South American tapir. Over the combination of 57 camera traps, there was a reasonable chance to detect the selected species. Our study assumed that we did have false detections and the absence of detection of a focal species over one period indicated that sites were truly unoccupied during the sampling period or species were very scarce at the sampled sites during the survey.

We used the species detection information to investigate the effects of spatial extent of habitat covariates on the probability of species occupancy. We ran occupancy models for which occupancy probability $\Psi$ at each camera trap location and the detection probability $\mathrm{p}$ were modelled as a linear function of covariates $\mathrm{x}_{\mathrm{i}}$ using logit link functions (see Niedballa et al. 2015 for details). We ran models for each buffer size and species. First, we determined for each species how the probability of detection $\mathrm{p}$ should be implemented in null models. We used a stepwise approach starting with a model $\Psi() p.($.$) where both occupancy and detection probabilities were constant (i.e.,$ fixed as 1). As density of understory and weather could affect detection probability around the camera traps, we created two covariates called visibility (contrasting open vs. dense understory) and weather (contrasting rainy $v$ s. dry season). Then we ran three other models $\Psi(.) \mathrm{p}\left(\mathrm{x}_{\mathrm{i}}\right)$ to test whether covariates $\mathrm{x}_{\mathrm{i}}$ including visibility around camera trap and weather, or both, affected detection probability $\mathrm{p}$ with occupancy probability $\Psi$ constant. We compared these four models of detection ( $($ (.)p(.), $\Psi(.) \mathrm{p}$ (visibility), $\Psi(.) \mathrm{p}$ (weather), $\Psi(.) \mathrm{p}$ (visibility, weather) using AIC and selected the model with the lowest AIC and $\triangle \mathrm{AIC}$ higher than 2 with the closest competing model. Finally, from this selected (null) model of detection, we tested the effects of landscape metrics on occupancy probability $\Psi$ at each of the 8 buffer sizes and three landscape metrics calculated from the three forest cover maps $(25,50$ and $75 \%)$. Thus, for each landscape metric, we ran 8 models that we compared using AIC and null models. All models showing $\triangle \mathrm{AIC}<2$ from the best fitted models had similar statistical supports. Estimates $( \pm \mathrm{SE})$ of landscape metrics with their P-values affecting 

政

occupancy probability were extracted from the best candidate models. Statistical analyses were performed using R 3.6.2 (R Development Core Team 2019).

\section{Results}

Performance of models run at different spatial extents highlighted scale of effects of landscape metrics on the occurrence of three species. Indeed, buffer sizes that showed the strongest statistical supports (i.e. $\triangle \mathrm{AIC}<2$ ) ranged from 500 to $1500 \mathrm{~m}$ in ED (Fig. 3a) and 500 to $2000 \mathrm{~m}$ in FC (Fig. 3i) in Azara's agouti, from 500 to $750 \mathrm{~m}$ in FC in collared peccary (Fig. 3j) and $750 \mathrm{~m}$ in PD in brown brocket deer (Fig. 3g) when percent tree cover was higher than 75\% (Electronic appendix Table S2). For the other situations in the three species, we did not detect a scale of effects as null models including only covariates on detection probability p provided similar statistical models than candidate models including covariates affecting occupancy probability $\Psi$ (Electronic appendix Table S2). The South American tapir did not exhibit any scale of effect for the three landscape metrics (Fig 3d, h, 1).

When the threshold of the percent tree cover used to map forest, cover decreased (from 75 to $50 \%$ and from 50 to $25 \%$ ), we observed 3 different patterns from the performance of models at the different buffer sizes (Electronic appendices Table S2-4). The range of selected buffer sizes (i.e. the scale of effect) (1) remained similar as for instance in FC in collared peccary, (2) decreased as in Azara's agouti in ED, or (3) was no longer consistent in PD in brown brocket deer (Table 2). Although a range of selected models emerged at 50\% tree cover in PD in Azara's agouti, we did not detect any significant effect of this variable (i.e., $\mathrm{P}>0.05$, Table 2). Thus, we did not consider this result as robust. Altogether, our analyses suggest that the species exhibit a stronger scale of effect when considering high tree cover (e.g. $75 \%$ ) compared to medium-low tree cover $(50-25 \%)$.

Finally, regarding the estimate $(\beta) \pm$ SE associated with the significant effect of each landscape metric extracted from the candidate models with the lowest AIC (buffer size indicated with * in Table 2), the occurrence of Azara's agouti and collared peccary increased with FC, brown brocket deer with PD, and Azara's agouti with ED when the threshold on percent tree cover was $75 \%$. When this threshold decreased, the trend did not change in FC as in collared peccary although the strength of the effect felt to nearly significant value in Azara's agouti (Table 2).

\section{Discussion}


Scales of effects varied among mammal species from the Brazilian savannahs, and this variation could be partially explained by species traits, but most importantly, was strongly influenced by how we define forests.

The scale of effect of Azara's agouti ranged from 500 to $2000 \mathrm{~m}$ (for FC and ED), while for collared peccary it ranged from 500 to $750 \mathrm{~m}$ (FC), and for brown brocket deer it was $750 \mathrm{~m}$ (PD). The South American tapir did not exhibit any scale of effect on the three landscape metrics. Thus, the spatial extents that have been detected suggest that ecological and behavioural mechanisms underlying the scale of effects occurred at local scale and were associated with habitat selection and home range as reported in medium and large-body-sized herbivore species (Johnson 1980; Danell et al. 2006). These results also suggest that a range of spatial extents (from 500 to $2000 \mathrm{~m}$ in this study) should be considered rather than a particular buffer size in the scale of effect of landscape metrics on species occurrence (Moraga et al. 2019). The ability of some species to live or use fragmented sites depended on their biological traits such as body size (Cardillo et al. 2005), ecological requirements (Miguet et al. 2016) or their ability to cross harsh habitats (Pires et al. 2002). We predicted that scale of effect would be larger for larger-bodied species because they are more mobile, tend to be move farther and their home range are higher than smaller-bodied species (Bowman et al. 2002; Jackson and Fahrig 2015). From performance of models with $75 \%$ tree cover, we did not detect that scale of effect was larger in the largest studied species, the South American tapir, and the scale of effect overlapped highly among the Azara's agouti, collared peccary and brown brocket deer. Thus, body-size as indicator or animal mobility may not be a very strong predictor of the scale of effect in our four studied tropical herbivorous species. The effect of the dispersal distance on the scale of effect need to be tested on a wide range of species including micromammals to address overall conclusions.

Contrary to the two studied generalist species, the South American tapir and brown brocket deer, the two forest-dwelling species, the Azara's agouti and collared peccary, exhibited a scale of effect on FC. These results might show that species that are more generalist in their habitat requirements might not be limited by forest cover using agricultural landscape with open areas to achieve their ecological requirements (e.g., food). A previous study in Brazilian Amazon reported that the lowland tapir was one of the species with a high ability to survive in more altered environments including regeneration areas with food opportunities (Teixeira-Santos et al. 2020). The lack of scale of effect on the occurrence of the South American tapir might also be observed if the response is not scale dependent (Martin and Fahrig 2012) or the landscape heterogeneity does not allow to investigate pattern at a larger scale in species with high dispersal range $(>3 \mathrm{~km}$ for this species, Table 1). As in our study area, landscape variables remain quite fixed beyond a buffer radius of $3 \mathrm{~km}$ (Electronic Appendices Table S1 and Fig. S1), the opportunity to detect scale of 
344 effect beyond this distance might be limited. Finally, as the effect of ecological traits might interact 345 to explain the scale of effect of forest cover on species occurrence (as for instance the studied 346 smaller bodied size species were the forest-dwelling ones), more studies are needed to clarify the 347 role of uncorrelated traits in a larger range of species.

348 Landscape features might affect the scale of effect on species occurrence. Lyra-Jorge et al.

349 (2010) reported that two large and highly mobile carnivores, Puma concolor and Chrysocyon

350 brachyurus, were best explained by edge density of the native vegetation at a coarse scale of $2 \mathrm{~km}$.

351 Our analyses showed that species that mainly use forest edges, the Azara's agouti and the collared

352 peccary, exhibited a scale of effect on metrics associated to landscape configuration such as ED and

353 PD. Regolin et al. (2017) reported that the richness of carnivores community increased with forest

354 cover and decreased with landscape fragmentation. Bogoni et al. (2018) showed that large

355 herbivores decreased when native vegetation cover, forest fragment size, and the largest

356 neighbouring patch of remnant forest decreased. Here, as the studied species exhibited different

357 patterns of scale of effect with the landscape metrics, our results supported previous studies

358 showing that landscape composition and configuration are both important drivers in shaping 359 occurrence of terrestrial mammals in native forests (Ochoa-Quintero et al. 2015; Regolin et al.

360 2017). Unfortunately, among the four selected species, we do not have one mammal species that did 361 not require forest.

362 While different percentages of tree cover have been used in the literature to map forest cover

363 (Defries et al. 2001; Hansen et al. 2010), studies were reporting that occurrence of terrestrial

364 mammal species was affected by forest cover (Chiarello 2000; Michalski and Peres 2007) and

365 vegetation types (Lyra-Jorge et al. 2010). However, few studies have examined whether the percent

366 tree cover used to map forest cover affect the scale of effect of landscape metrics on the occurrence

367 of species. Overall, our analyses showed that species exhibited a stronger scale of effect when

368 considering high tree cover (e.g., $75 \%$ ) compared to medium-low tree cover $(50-25 \%)$. Thus, the

369 detection of scale of effect varies with habitat definition. While the percent tree cover used to map

370 forest cover shaped patch-based landscape metrics and thus the assessment of land use and land

371 cover composition and spatial configuration, it also determines our ability to detect the correct scale

372 of effects for species. This is a new and important result, which implies that before using multiple

373 sizes of buffers to test the scale of effects, we need a previous and decisive step, which is to define

374 correctly habitat types of species. However, defining properly what is an "habitat" is challenging,

375 particularly for species living in complex mosaic of vegetation types including forests, savannas

376 and grasslands (Bonanomi et al. 2019) showing for instance environment gradients. Several

377 percentages of tree cover have been used in the literature to map forest cover (Defries et al. 2001;

378 Hansen et al. 2010). Although changing the percent tree cover allows to select different amount of 
canopy, it also affects the type of vegetation and thus habitat for species (Hirota et al. 2011). These results are particularly important in the current landscape dynamics occurring in the Cerrado. In the last decades, agriculture expansion at the expense of native vegetation dramatically increased landscape fragmentation (Strassburg et al. 2017) and the need to investigate the mechanism underlying the response of biodiversity to the erosion of native vegetation (e.g., forest cover) has been a critical topic for conservation purposes in Brazil (Pardini et al. 2010; Martensen et al. 2012; Banks-Leite et al. 2014; Ochoa-Quintero et al. 2015).

Implications for conservation and land planning Although the spatial extent (scale) at which landscape attributes are measured has a substantial impact on inferred species-landscape relationships, the way that habitats are defined has a critical impact on the scale of effect analysis. As mammal species might respond differently to forest cover (Chamaillé-Jammes et al. 2016; Zimbres et al. 2018), the question whether forest cover (i.e., percent tree cover) has been appropriately selected to link landscape metrics on the occurrence of species appears as the first main concern to avoid failure in conservation initiatives. Here we recommend using and testing multiple definitions of habitats to assess the ecological requirements of studied species. Although $75 \%$ tree cover seems to be a good proxy of forest cover to study the forestdwelling species in our study area, this might also be the case for other variables of landscape composition that are characterised by a continuous gradient such as agriculture or urbanisation. Moreover, from a conservation perspective, it is critical to test multiple scales at which species respond to the landscape variables. In the Cerrado, we recommend that initiatives examining spatial arrangement of landscape attributes of forest cover in relation to populations in terrestrial mammals (from small to large body sized species) should consider buffer sizes from 500 to $2000 \mathrm{~m}$. However, the puzzle is far more complicated with questions regarding communities. No management approach based on a single scale would benefit all species (Crouzeilles and Curran 2016; Bhakti et al. 2018). It might be important to analyse a large range of species and set targets for each one using specific scales. This should be relevant in the context of systematic planning approaches and multiscale management based on the responses of multiple species (Neel et al. 2004). Thus, using multiple definitions of habitats and scales is critical as most initiatives of ecological zoning, biodiversity prioritizing or ecosystem restoration use landscape units that have a particular meaning in terms of land use dynamics and planning (usually justified by physical constraints) but not in terms of functional responses of the organisms. 


\section{Acknowledgements}

413 This work was funded by a CAPES (Coordenação de Aperfeiçoamento de Pessoal de Nível

414 Superior, Brazil) COFECUB (Comité Français d'Évaluation de la Coopération Universitaire et

415 Scientifique and Campus France) grant (French number: Sv 875-17 and Brazilian Process:

416 23038.001818/2020-70), the Institutional Program of Internationalization sponsored by the CAPES

417 (Finance Code 001; Capes-PrInt 41/2017 - Process: 88881.311897/2018-01), the Conselho

418 Nacional de Desenvolvimento Científico e Tecnológico (CNPq Process: 301306/2018-4) and the

419 Pesquisa Ecológica de Longa Duração (PELD/ILTER) Planalto da Bodoquena and the University

420 of Angers (FragHerb project). We would like to thank the Programa de Pós Graduação em

421 Ecologia e Conservação (PPGEC) of the Universidade Federal de Mato Grosso do Sul (UFMS),

422 the CAPES, the COFECUB, Campus France, the Fundação de Apoio ao Desenvolvimento do

423 Ensino, Ciência e Tecnologia do Estado de Mato Grosso do Sul (FUNDECT) for their institutional

424 supports and Jacques Baudry for his helpful comments.

\section{References}

428 Aliaga-Rossel E, Kays R, Fragoso J (2008) Home-range use by the Central American agouti

429 (Dasyprocta punctata) on Barro Colorado Island, Panama. J Trop Eco 124: 367-374

430 Arévalo-Sandi A, Bobrowiec PED, Chuma VJUR, Norris D (2018) Diversity of terrestrial mammal $431 \quad$ seed dispersers along a lowland Amazon forest regrowth gradient. PloS one 13: e0193752.

432 Banks-Leite C, Pardini R, Tambosi LR, Pearse WD, Bueno AA, Bruscagin RT, Condez TH, Dixo

433 M, Igari AT, Martensen AC, Metzger JP (2014) Using ecological thresholds to evaluate the 434 costs and benefits of set-asides in a biodiversity hotspot. Science 345: 1041-1045

435 Bastian O, Krönert R, Lipský (2006) Landscape diagnosis on different space and time scales - a $436 \quad$ challenge for landscape planning. Landsc Ecol 21: 359-374

437 Bhakti T, Goulart F, de Azevedo CS, Antonini Y (2018) Does scale matter? The influence of three$438 \quad$ level spatial scales on forest bird occurrence in a tropical landscape. PlosONE 13: e0198732 439 Bennett B (2002) What is a forest? on the vagueness of certain geographic concepts. Topoi 20:189440 201Bennett A, Radford JQ, Haslem A (2006) Properties of land mosaics: implications for nature conservation in agricultural environments. Biol Conserv 133: 250-264

Bodmer RE (1989) Ungulate biomass in relation to feeding strategy within Amazonian forests. Oecologia 81: 547-550

Bodmer RE (1991) Strategies of seed dispersal and seed predation in Amazonian ungulates. Biotropica 23: 255-261 
Bogoni JA, Graipel ME, Oliveira-Santos LGR, Cherem JJ, Giehl EL, Peroni N (2017) What would be the diversity patterns of medium- to large-bodied mammals if the fragmented Atlantic Forest was a large metacommunity? Biol Conserv 211: 85-94

Bonanomi J, Tortato FR, Gomes FSR, Penha JM, Bueno AS, Peres CS (2019) Protecting forests at the expense of native grasslands: Land-use policy encourages open-habitat loss in the Brazilian cerrado biome. Perspect Ecol Conser 17: 26-31

Boscolo D, Metzger JP (2009) Is bird incidence in Atlantic forest fragments influenced by landscape patterns at multiple scales? Landsc Ecol 24: 907-918

Bovendorp RS, Brum FT, McCleery RA, Baiser B, Loyola R, Cianciaruso MV, Galetti M (2019) Defaunation and fragmentation erode small mammal diversity dimensions in tropical forests. Ecography 42: 23-35

Bowman J, Jaeger JAG, Fahrig L (2002) Dispersal distance of mammals is proportional to home range size. Ecology 83: 2049-2055

Brennan JM, Bender DJ, Contreras TA, Fahrig L (2002) Focal patch landscape studies for wildlife management: optimizing sampling effort across scales. In: Liu J, Taylor WW (eds.) Integrating landscape ecology into natural resource management. Cambridge University Press, Cambridge, pp 68-91

Cardillo M, Mace GM, Jones KE, Bielby J, Bininda-Emonds ORP, Sechrest W, Orme CDL, Purvis A (2005) Multiple causes of high extinction risk in large mammal species. Science 309: 12391241

Chaplin-Kramer R, de Valpine P, Mills NJ, Kremen C (2013) Detecting pest control services across spatial and temporal scales Agric Ecosyst Environ 181: 206-212

Chase JM, Leibold MA (2002) Spatial scale dictates the productivity-biodiversity relationship. Nature 416: 427-430

Chamaillé-Jammes S, Charbonnel A, Dray S, Madzikanda H, Fritz H (2016) Spatial Distribution of a Large Herbivore Community at Waterholes: An Assessment of Its Stability over Years in Hwange National Park, Zimbabwe. PLoS ONE 11: e0153639

Chazdon RL, Pedro HS, Brancalion LL, Bennett-Curry A, Buckingham K, Kumar C, Moll-Rocek J, Vieira ICG, Wilson SJ (2016) When is a forest a forest? Forest concepts and definitions in the Era of forest and landscape restoration.” Ambio 45 (5): 538-550. doi:10.1007/s13280-0160772-y

Chiarello AG (2000) Density and populations size of mammals in remnants of Brazilian Atlantic Forest. Conserv Biol 14:1649-1657

Cid B, Oliveira-Santos LGR, Mourão G (2013) Seasonal habitat use of Agoutis (Dasyprocta azarae) is driven by the palm Attalea Phalerata in Brazilian Pantanal. Biotropica 45: 380-385 
Comber A, Fisher P, Wadsworth R (2005) You know what land cover is but does anyone else?... an investigation into semantic and ontological confusion. Int J Remote Sens 26: 223-228

Crawley MJ, Harral JE (2001) Scale dependence in plant biodiversity. Science 291: 864-868

Crouzeilles R, Curran M (2016) Which landscape size best predicts the influence of forest cover on restoration success? A global meta-analysis on the scale of effect. J Appl Ecol 53: 440-448

Danell K, Bergström R, Duncan P, Pastor J (2006) Large herbivores and ecosystem functioning. Cambridge University Press, Cambridge

Defries RS, Hansen MC, Townshend JRG, Janetos AC, Loveland TR (2001) A new global 1-km dataset of percentage tree cover derived from remote sensing. Global Change Biol 6: 247-254.

Delsol R, Loreau M, Haegeman B (2018) The relationship between the spatial scaling of biodiversity and ecosystem stability. Glob Ecol Biogeogr 27: 439-449

Duarte JMB, Vogliotti A, Zanetti EV, Oliveira ML, Tiepolo LM, Rodrigues LF, Almeida, LB (2012) Avaliação do risco de extinção do veado-catingueiro Mazama gouazoubira G. Fischer [von Waldheim], 1814, no Brasil. Biodiversi Brasil, 3: 50-58

Eisenberg JF, Redford KH (1999) Mammals of the Neotropics: volume 3: the central Neotropics. University of Chicago Press, Chicago, Illinois.

Fahrig L, Baudry J, Brotons L, Burel FG, Crist TO, Fuller RJ, Martin JL (2011) Functional landscape heterogeneity and animal biodiversity in agricultural landscapes. Ecol Lett 14: 101112.

Ferreguetti AC, Tomas WM, Fergallo HG (2017) Differences in the mammalian habitat use in a mosaic of vegetation types of an Atlantic rain-forest Reserve, Brazil. Mastozool Neotrop 24: $355-364$

Fiske I, Chandler R (2011) unmarked: An R Package for Fitting Hierarchical Models of Wildlife Occurrence and Abundance. J Stat Softw 43: 1-23

Fortin D, Courtois R, Etcheverry P, Dussault C, Gingras A (2008) Winter selection of landscapes by woodland caribou: behavioural response to geographical gradients in habitat attributes. J Appl Ecol 45:1392-1400

Fragoso JMS (1998) Home Range and movement patterns of white-lipped Peccary (Tayassu pecari) Herds in the Northern Brazilian Amazon. Biotropica 30: 458-469

Fryxell JM, Hazell M, Börger L, Dalziel BD, Haydon DT, Morales JM, McIntosh T, Rosatte RC (2008) Multiple movement modes by large herbivores at multiple spatiotemporal scales. Proc Natl Acad Sci USA 105: 19114-19119

Gabriel D, Sait SM, Hodgson JA, Schmutz U, Kunin WE, Benton TG (2010) Scale matters: the impact of organic farming on biodiversity at different spatial scales. Ecol Lett 13: 858-869 
515

Hansen MC, Potapov PV, Moore R, Hancher M, Turubanova SA, Tyukavina A, Thau D, Stehman SV, Goetz SJ, Loveland TR, Kommareddy A (2013) High-resolution global maps of 21 stcentury forest cover change. Science 342: 850-853

Hansen MC, Stehman SV, Potapov PV (2010) Quantification of global gross forest cover loss. Proc Natl Acad Sci USA 107: 8650-8655

Hirota M, Holmgren M, Van Nes EH, Scheffer M (2011) Global Resilience of Tropical Forest and Savanna to Critical Transitions. Science 334: 232-235

Holland J, Bert DG, Fahrig L (2004) Determining the spatial scale of species' response to habitat. Bioscience 54: 227-233

Holland J, Yang S (2016) Multi-scale studies and the ecological neighbourhood. Curr Landsc Ecol Rep 1: 135-145

Huais PY (2018) multifit: an R function for multi-scale analysis in landscape ecology. Landsc Ecol 33: $1023-1028$

Jackson HB, Fahrig L (2012) What size is a biologically relevant landscape? Landsc Ecol 27: 929_ 941

Jackson HB, Fahrig L (2015) Are ecologists conducting research at the optimal scale? Glob Ecol Biogeogr 24: 52-63

Johnson DH (1980) The comparison of usage and availability measurements for evaluating resource preference. Ecology 61: 65-71

Jansen PA, Hirsch BT, Emsens W-J, Zamora-Gutierrez V., Wikelski M, Kays R (2012) Thieving rodents as substitute dispersers of megafaunal seeds. Proc Natl Acad Sci USA 109: 1261012615

Johnson DH (1980) The comparison of usage and availability measurements for evaluating resource preference. Ecology 61: 65-71

Judas J, Henry O (1999) Seasonal variation of home range of collared peccary in tropical rain forest of French Guiana. J Wildl Manag 63: 546-552

Keuroghlian A, Eaton DP, Longland WS (2004) Area use by white-lipped and collared peccaries (Tayassu pecari and Tayassu tajacu) in a tropical forest fragment. Biol Conserv 120:411-25

Klink CA, Machado RB (2005) Conservation of the Brazilian Cerrado. Conserv Biol 19: 707-713 Leibold MA, Holyoak M, Mouquet N, Amarasekare P, Chase JM, Hoopes MF, Holt RD, Shurin JB, Law R, Tilman D, Loreau M, Gonzalez A (2004) The metacommunity concept: a framework for multi-scale community ecology. Ecol Lett 7: 601-613

Levin SA (1992) The problem of pattern and scale in Ecology. Ecology 73: 1943-1967

Lidicker Jr WZ (1999) Responses of mammals to habitat edges: a landscape perspective. Landsc Ecol 14: 331 
550

551

552

553

554

555

556

557

558

559

560

561

562

563

564

565

566

567

568

569

570

Lowicki D (2017) Landscape metrics as an indicators of landscape value. Probl Landsc Ecol Vol. 44: 99-108

Lü Y, Feng X, Chen L, Fu B (2013) Scaling effects of landscape metrics: a comparison of two methods. Phys Geog 34: 40-49

Lyra-Jorge MC, Ribeiro MC, Ciocheti C, Tambosi LR, Pivello VR (2010) Influence of multi-scale landscape structure on the occurrence of carnivorous mammals in a human-modified savanna, Brazil. Eur J Wildlife Res 56: 359-368

Mares MA, Ernest KA, Gettinger RD (1986) Small mammal community structure and composition in the Cerrado province of Central Brazil. J Trop Ecol 2: 289-300

Martensen AC, Ribeiro MC, Banks-Leite C, Prado PI, Metzger JP (2012) Associations of Forest Cover, Fragment Area, and Connectivity with Neotropical Understory Bird Species Richness and Abundance. Conserv Biol 26: 1100-1111

Martin AE, Farhig L (2012) Measuring and selecting scales o effect for landscape predictors in species-habitat models. Ecol Appl 22: 2277-2292

Mayor SJ, Schneider DC, Schaefer JA, Mahoney SP (2009) Habitat selection at multiple scales. Ecoscience 16: 238-247

Melo GL, Sponchiado J, Cáceres N, Fahrig L (2017) Testing the habitat amount hypothesis for South American small mammals. Biol Conser 209: 304-314

Michalski F, Peres CA (2007) Disturbance-mediated mammal persistence and abundance-area relationships in Amazonian forest fragments. Conserv Biol 21:1626-1640

Miguet P, Jackson HB, Jackson ND, Martin AE, Fahrig L (2016) What determines the spatial extent of landscape effects on species? Landsc Ecol 31: 1177-1194

Miguet P, Fahrig L, Lavigne C (2017) How to quantify a distance-dependent landscape effect on a biological response. Methods Ecol Evol 8: 1717-1724

Moraga AD, Martin AE, Fahrig L (2019) The scale of effect of landscape context varies with the species' response variable measured. Landsc Ecol 34: 703-715

Haines-Young R (2009) Land use and biodiversity relationships. Land Use Policy 26: 178-186

Neel MC, McGarigal K, Cushman SA. (2004) Behavior of class-level landscape metrics across gradients of class aggregation and area. Landsc Ecol 19: 435-455

Newbold T, Hudson LN, Hill SLL et al (2015) Global effects of land use on local terrestrial biodiversity. Nature 520: 45-50

Niedballa J, Sollmann R, bin Mohamed A, Bender J (2015) Defining habitat covariates in cameratrap based occupancy studies. Sci Rep 5: 17041

Ochoa-Quintero JM, Gardner TA, Rosa I, de Barros Ferraz SF, Sutherland WJ (2015) Thresholds of species loss in Amazonian deforestation frontier landscapes. Conserv Biol 29: 440-451 
Oliveira PS, Marquis RJ (2002) The Cerrados of Brazil: Ecology and Natural History of a Neotropical Savanna, Columbia University Press, New York/USA. 373p.

Pardini R, de Buen, AA, Gardner TA, Prado PI, Metzger JP (2010) Beyond the fragmentation threshold hypothesis: Regime shifts in biodiversity across fragmented landscapes. PLoS ONE 5: e13666

Pires AS, Lira PK, Fernandez FAS, Schittini GM, Oliveira LC (2002) Frequency of movements of small mammals among Atlantic Coastal Forest fragments in Brazil. Biol Cons 108: 229-237

Püttker T, Crouzeilles R, Almeida-Gomes M, Schmoeller M, Maurenza D, Alves-Pinto H, Pardini R, Vieira MV, Banks-Leite G, Fonseca CR et al. (2020) Indirect effects of habitat loss via habitat fragmentation: Across-taxa analysis of forest-dependent species. Biol Cons 241: 108368

Rahbek C (2005) The role of spatial scale and the perception of large-scale species-richness patterns. Ecol Lett 8: 224-239

Rausch LL, Gibbs HK, Schelly I, Brandão A, Morton DC, Filho AC, Strassburg B, Walker N, Noojipady P, Barreto P, Meyer D (2019) Soy expansion in Brazil's Cerrado. Conserv Lett 12: e12671Redon M, Bergès TC, Luque S (2014) Effects of increasing landscape heterogeneity on local plant species richness: how much is enough? Landsc Ecol 29: 773-787

Regolin AL, Cherem JJ, Graipel ME, Bogoni JA, Ribeiro JW, Vancine MH, Tortato MA, OliveiraSantos LG, Fantacini FM, Luiz MR, de Castilho PV, Ribeiro MC, Cáceres NC (2017) Forest cover influences occurrence of mammalian carnivores within Brazilian Atlantic Forest. J Mammal 98: 1721-1731

Rocchini D, Foody GM, Nagendra H, Ricotta C, Anand M, He KS et al. (2013) Uncertainty in ecosystem mapping by remote sensing. Comput Geosci 50:128-135.

Royo AA, Carson WP (2005) The herb community of a tropical forest in central Panamá: dynamics and impact of mammalian herbivores. Oecologia 145: 66-75

Saab V (1999) Importance of spatial scale to habitat use by breeding birds in riparian forests: a hierarchical analysis. Ecol Appl 9: 135-151

Schuster R Römer H, Germain RR (2013) Using multi-scale distribution and movement effects along a montane highway to identify optimal crossing locations for a large-bodied mammal community. PeerJ 1: e189

Strahler AH, Woodcock CE, Smith JA (1986) On the nature of models in remote sensing. Remote Sens Environ 20: 121-139

Strassburg BBN, Brooks T, Feltran-Barbieri R, Iribarrem A, Crouzeilles R, Loyola R, Latawiec AE, Oliveira Filho FJB, Scaramuzza CAM, Scarano FR, Soares-Filho B, Balmford A (2017) Moment of truth for the Cerrado hotspot. Nat Ecol Evol 1: 99 
620 Teixeira-Santos J, Ribeiro ACdC, Wiig Ø, Pinto NS, Cantanhêde LG, Sena L, et al. (2020)

621 Environmental factors influencing the abundance of four species of threatened mammals in 622 degraded habitats in the eastern Brazilian Amazon. PLoS ONE 15: e0229459

623 Thornton DH, Fletcher RJ (2014) Body size and spatial scales in avian response to landscapes: a 624 meta-analysis. Ecography 37: 454-463

625 Vanderwal J, Falconi L, Januchowski S, Shoo L, Storlie C (2014) Package 'SDMTools'. Species 626 Distribution ModellingTools: Tools for processing data associated with species distribution 627 modelling exercises. R-package version 1.1 .12

628 Villard M-A, Metzger JP (2014) Beyond the fragmentation debate: a conceptual model to predict 629 when habitat configuration really matters. J Appl Ecol 51: 309-318

630 Woodcock CE, Strahler AH (1987) The factor of scale in remote sensing. Remote Sens Environ 21: $631 \quad 311-332$

632 Young HS, McCauley DJ, Helgen KM, Goheen JR, Otárola-Castillo E, Palmer TM, Pringle RM, 633 Young TP, Dirzo R (2013) Effects of mammalian herbivore declines on plant communities: 634 observations and experiments in an African savanna. J Ecol 101: 1030-1041

635 Zimbres B, Peres CA, Penido G, Machado RB (2018) Thresholds of riparian forest use by terrestrial 636 mammals in a fragmented Amazonian deforestation frontier. Biodivers Conserv 27: 2815$637 \quad 2836$ 
639 Table 1. Ecological traits of the studied mammal species

\begin{tabular}{lcccll}
\hline Studied species & $\begin{array}{c}\text { Adult body } \\
\text { mass }(\mathrm{kg})\end{array}$ & $\begin{array}{c}\text { Home range } \\
\text { (ha) }\end{array}$ & $\begin{array}{c}\text { Dispersal } \\
\text { range }(\mathrm{m})\end{array}$ & Habitat use & References \\
\hline Azara's agouti & 2.9 & $1.34-2.45$ & $100-500$ & $\begin{array}{c}\text { Forest/ } \\
\text { edges }\end{array}$ & $\begin{array}{l}\text { Aliaga-Rossel et al. 2008; } \\
\text { Jansen et al. 2012; Cid et al. } \\
2013\end{array}$ \\
\hline Brown brocket deer & 21 & $2.7-348$ & $750-1000$ & $\begin{array}{c}\text { Forest/ } \\
\text { open area }\end{array}$ & $\begin{array}{l}\text { Duarte et al. 2012; Pires et al. } \\
2018\end{array}$ \\
\hline Collared peccary & 22 & $24-800$ & $500-1000$ & $\begin{array}{c}\text { Forest/ } \\
\text { edges }\end{array}$ & $\begin{array}{l}\text { Bodmer 1991; Fragoso 1998; } \\
\text { Judand Henry 1999; }\end{array}$ \\
\hline South American tapir & 225 & $0.1-100$ & $>3000$ & $\begin{array}{c}\text { Forest/ } \\
\text { open area }\end{array}$ & $\begin{array}{l}\text { Bodmer 1989; Emmons and Feer } \\
1997 ; \text { Pires et al. 2018 }\end{array}$ \\
\hline
\end{tabular}


640 Table 2. Results of occupancy models predicting the occurrence of four species of terrestrial mammals across buffer size (from 500 to $10000 \mathrm{~m}$ )

641 considering three threshold of percent tree cover per pixel (25, 50 and 75\%). This table addressed the selected range of models (and thus buffer size)

642 that have been selected from AIC model selection (See Electronic Appendix Table S1 for details). Model structure refers to how occupancy probability

$643 \Psi$ at the camera trap $i$ and the detection probability $p$ were implemented. Analyses were carried out separately for each species and landscape metric

644 including edge density, ED, patch density, PD, and the percentage of forest cover, FC. When several models showed similar statistical support (i.e.

$645 \Delta$ AIC $<2$ ), estimate $(\beta) \pm$ SE was extracted for the model with the lowest AIC indicated by the * near the buffer size. Significant effects are indicated

in bold.

\begin{tabular}{|c|c|c|c|c|c|c|c|c|c|c|c|}
\hline \multirow{3}{*}{$\begin{array}{l}\text { Landscape } \\
\text { metric }\end{array}$} & \multirow{3}{*}{ Model structure } & \multirow{3}{*}{ Species } & \multicolumn{9}{|c|}{ Percent of tree cover per pixel } \\
\hline & & & \multicolumn{3}{|c|}{$25 \%$} & \multicolumn{3}{|c|}{$50 \%$} & \multicolumn{3}{|c|}{$75 \%$} \\
\hline & & & Buffer size & $\beta \pm \mathrm{SE}$ & $\mathrm{P}$ & Buffer size & $\beta \pm \mathrm{SE}$ & $\mathrm{P}$ & Buffer size & $\beta \pm \mathrm{SE}$ & $\mathrm{P}$ \\
\hline \multirow{4}{*}{ ED } & p (weather+visibility) $\Psi(E D)$ & Azara's agouti & & & & 500 & $0.325 \pm 0.185$ & 0.079 & $500 *-1500$ & $0.517 \pm 0.267$ & 0.053 \\
\hline & p (visibility) $\Psi$ (ED) & Brown brocket deer & & & & & & & & & \\
\hline & p (visibility) $\Psi$ (ED) & Collared peccary & & & & & & & & & \\
\hline & p (weather+visibility) $\Psi$ (ED) & South American tapir & & & & & & & & & \\
\hline \multirow{4}{*}{ PD } & $\mathrm{p}$ (weather+visibility) $\Psi(\mathrm{PD})$ & Azara's agouti & & & & $\begin{array}{l}1500-2000 *- \\
3000\end{array}$ & $-1.030 \pm 0.675$ & 0.128 & & & \\
\hline & p (visibility) $\Psi(\mathrm{PD})$ & Brown brocket deer & & & & & & & 750 & $0.643 \pm 0.305$ & 0.035 \\
\hline & $\mathrm{p}$ (visibility) $\Psi(\mathrm{PD})$ & Collared peccary & & & & & & & & & \\
\hline & $\mathrm{p}$ (weather+visibility) $\Psi(\mathrm{PD})$ & South American tapir & & & & & & & & & \\
\hline \multirow{4}{*}{$\mathrm{FC}$} & $\mathrm{p}$ (weather+visibility) $\Psi$ (FC) & Azara's agouti & $500 *-1500$ & $4.540 \pm 2.500$ & 0.070 & $500 *-2000$ & $5.050 \pm 2.890$ & 0.081 & $500-1500 *-2000$ & $9.000 \pm 4.450$ & 0.043 \\
\hline & p (visibility) $\Psi$ (FC) & Brown brocket deer & & & & & & & & & \\
\hline & p (visibility) $\Psi(\mathrm{FC})$ & Collared peccary & $500 *-1000$ & $2.690 \pm 1.400$ & 0.029 & $500 *-1000$ & $3.190 \pm 1.540$ & 0.039 & $500 *-750$ & $4.030 \pm 1.890$ & 0.033 \\
\hline & p (weather+visibility) $\Psi$ (FC) & South American tapir & & & & & & & & & \\
\hline
\end{tabular}


651 Fig. 1 Map of the study site, Bodoquena, state of Mato Grosso do Sul, Brazil (a) and forest cover

652 including the location of camera traps (b). Camera traps selected to run occupancy models (see 653 methods) are highlighted in red.

654

655 Fig. 2 Example of forest cover assessed for different threshold of "forest" definition (minimum tree 656 cover per pixel of 25, 50 and 75\%) around one camera trap at two buffers sizes, $3000 \mathrm{~m}$ (blue disc) 657 and $500 \mathrm{~m}$ (red disc). Forest pixels are represented in green.

659 Fig. 3 Comparison of model performance for the effect of landscape metric for forests defined with 660 a $75 \%$ of tree cover per pixel. The grey triangle is the null model in which occupancy probability is 661 fixed as 1 . The scale of effect is detected from spatial extent (i.e. the range of buffer sizes) for which $662 \Delta$ AIC $\leq 2$ included the smallest AIC without the null model (black dots). 
663

664 Fig.1

665

a

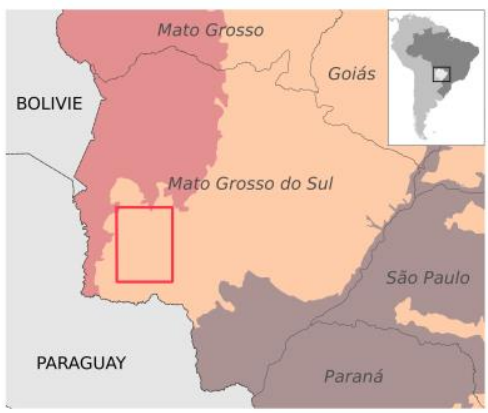

Cerrado biome

Mata Atlântica biome

Pantanal biome

$\square$ Study site

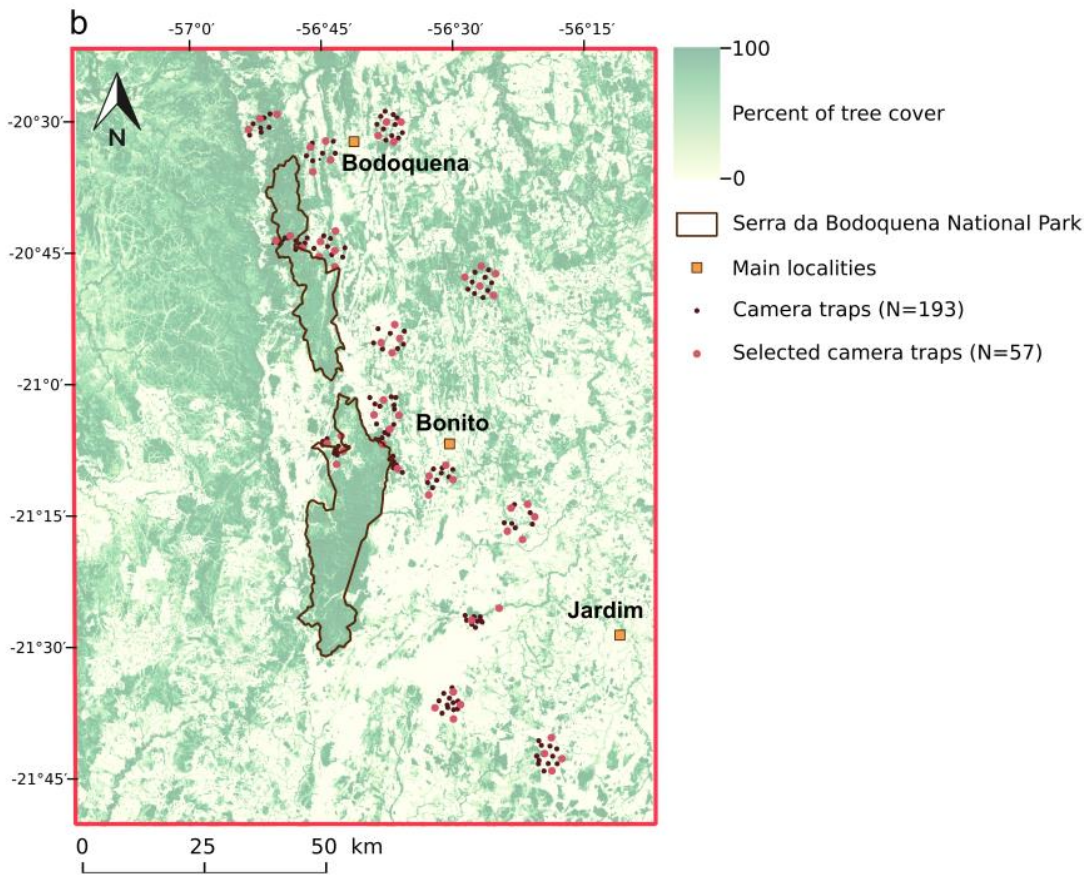


667 Fig. 2

668

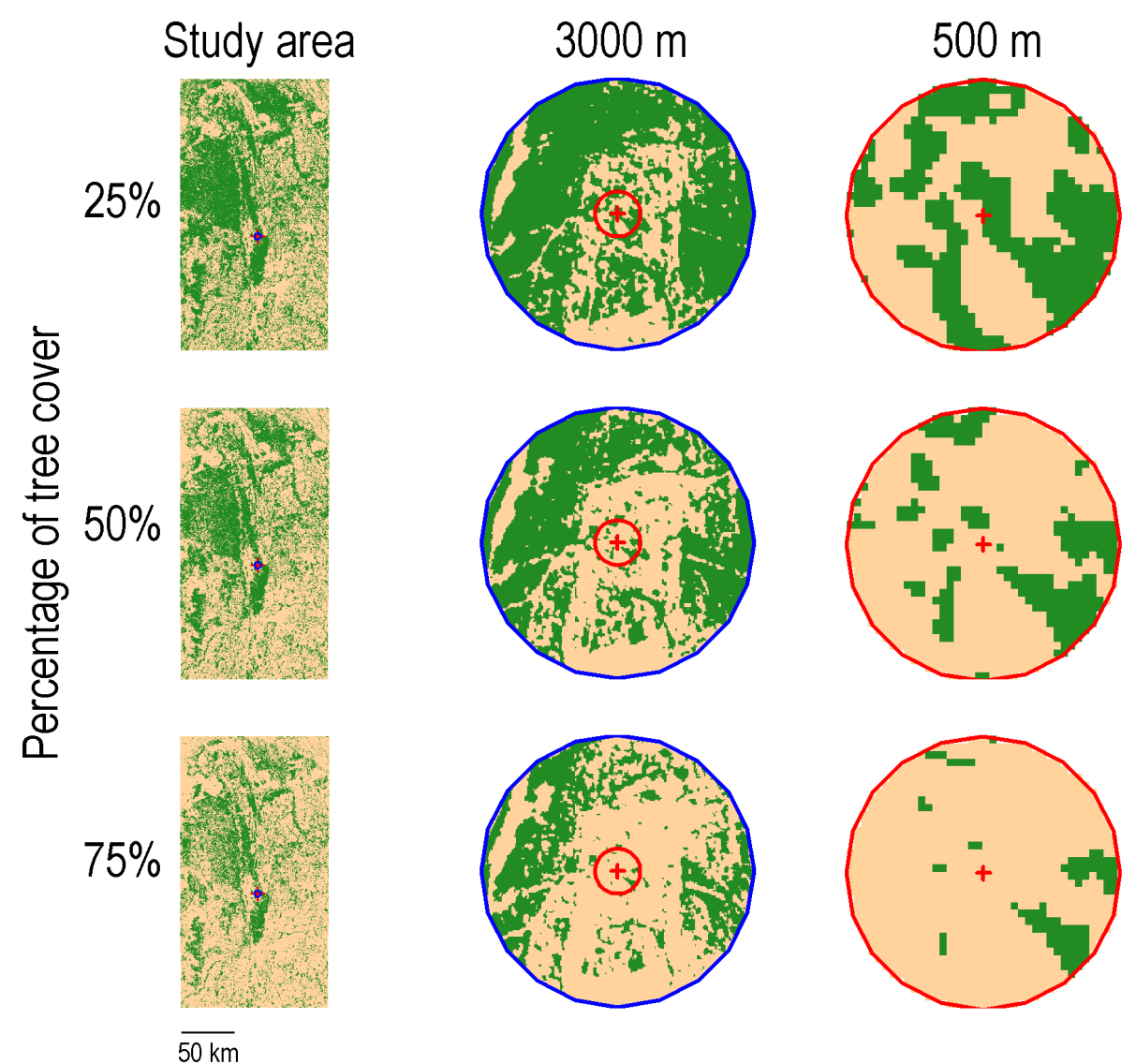

669 
671 Fig. 3

672

673

Azara's agouti

674
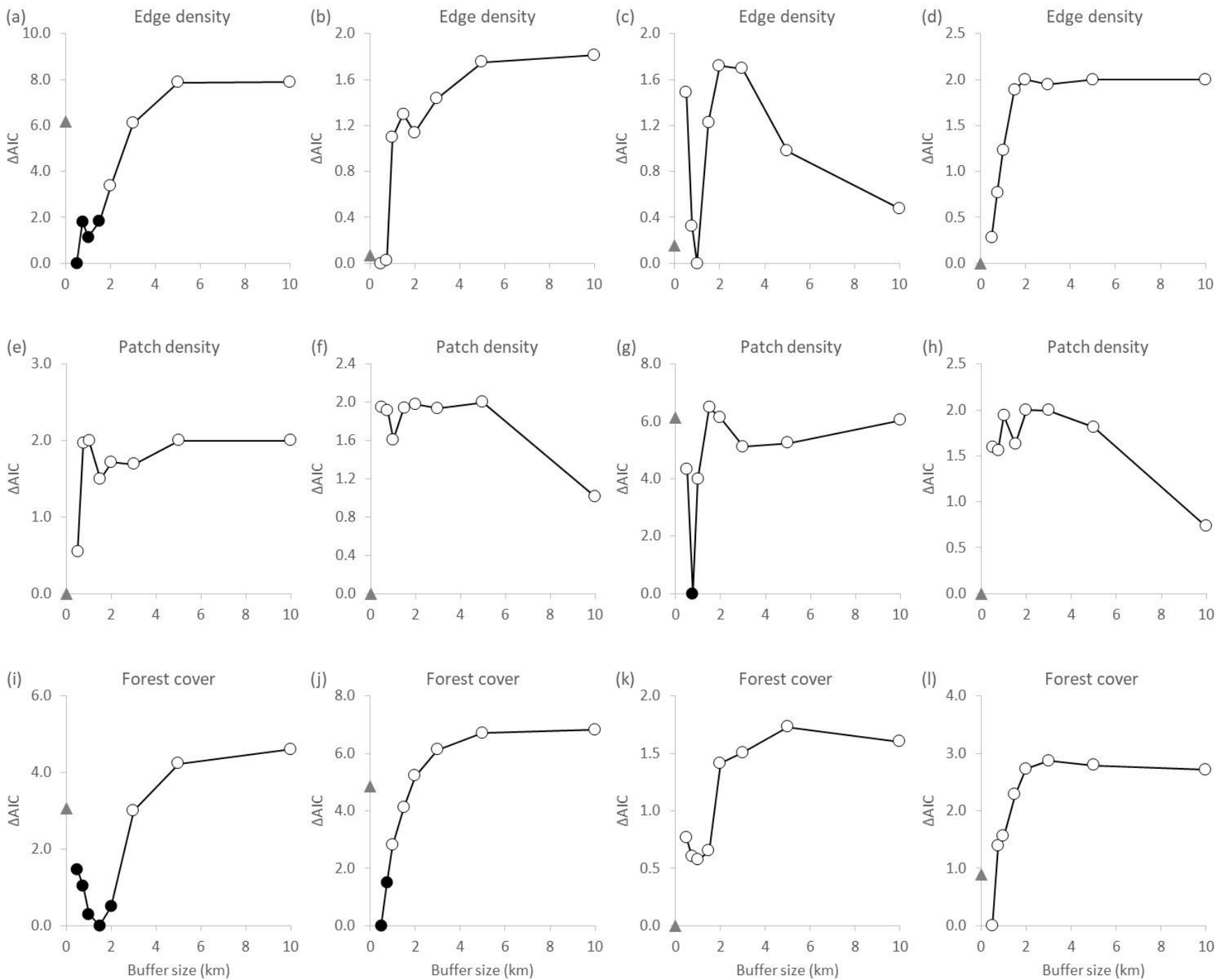


\section{Electronic appendices}

676
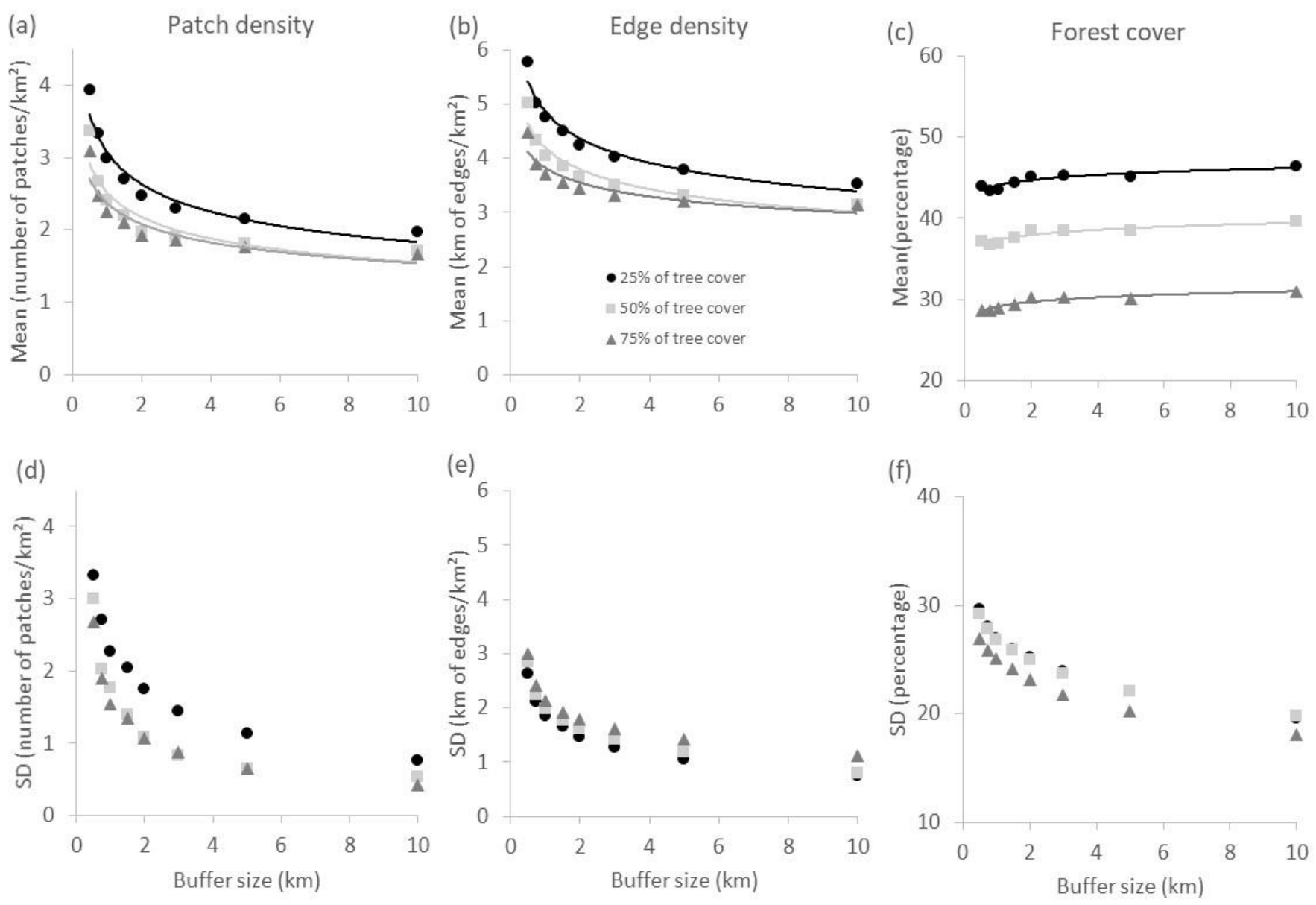

678 Fig. S1 Scaling relations with spatial extent (buffer size) of the mean values of landscape metrics,

679 patch density (a), edge density (b), forest cover (c) and their standard deviation (SD) (d, e, f)

680 assessed around our camera traps at three different percent tree cover per pixel (25, 50 and 75\%)

681 (See Table $\mathrm{S} 1$ for the statistics of the relationships in $\mathrm{a}, \mathrm{b}$ and $\mathrm{c}$ ).

682

683 
684 Table S1. Shape of the relationship between buffer size (x) and landscape metrics (y) including 685 patch density PD, edge density ED and the percent forest cover (FC) assessed at three percent tree 686 cover per pixel $(25,50$ and $75 \%)$. *** indicates that $\mathrm{P}$ value $<0.001$.

687

688

\begin{tabular}{lllll}
\hline Landscape metric & $\begin{array}{l}\text { Percent tree cover per } \\
\text { pixel }\end{array}$ & Relationship & Equation & $\mathrm{R}^{2}$ \\
\hline \multirow{4}{*}{ Patch Density } & $25 \%$ & Power*** & $\mathrm{y}=3.082 \mathrm{x}^{-0.226}$ & 0.94 \\
& $50 \%$ & Power*** & $\mathrm{y}=2.520 \mathrm{x}^{-0.211}$ & 0.87 \\
& $75 \%$ & Power*** & $\mathrm{y}=2.372 \mathrm{x}^{-0.189}$ & 0.87 \\
\hline \multirow{5}{*}{ Edge Density } & $25 \%$ & Power*** & $\mathrm{y}=4.868 \mathrm{x}^{-0.157}$ & 0.96 \\
& $50 \%$ & Power*** & $\mathrm{y}=4.196 \mathrm{x}^{-0.145}$ & 0.92 \\
& $75 \%$ & Power*** & $\mathrm{y}=3.823 \mathrm{x}^{-0.108}$ & 0.86 \\
\hline \multirow{3}{*}{ Forest Cover } & $25 \%$ & Logarithm*** & $\mathrm{y}=0.917 \ln (\mathrm{x})+44.058$ & 0.81 \\
& $50 \%$ & Logarithm*** & $\mathrm{y}=0.915 \ln (\mathrm{x})+37.312$ & 0.86 \\
& $75 \%$ & Logarithm*** & $\mathrm{y}=0.804 \ln (\mathrm{x})+29.143$ & 0.89 \\
\hline
\end{tabular}

689

690 
691 Table S2. Performance of occupancy models predicting the occurrence of four species of terrestrial 692 mammals (Azara's agouti Dasyprocta azarae, collared peccary Pecari tajacu, brown brocket deer 693 Mazama gouazoubira, and South American tapir Tapirus terrestris,) in the Brazilian Cerrado 694 hotspot across buffer size (from 500 to $10000 \mathrm{~m}$ ) considering $75 \%$ as the threshold of tree cover. 695 Model structure mentions how occupancy probability $\Psi$ at the camera trap i and the detection 696 probability $\mathrm{p}$ were implemented. Analyses were carried out separately for each species and 697 landscape metric including edge density, ED, patch density, PD, and the percentage of forest cover, 698 FC. Buffer size is indicated in $\mathrm{m}$. AIC is the Akaike criterion. Models of similar statistical supports 699 with $\triangle \mathrm{AIC}<2$ from the minimum model are in bold.

\begin{tabular}{|c|c|c|c|c|c|c|c|c|c|c|c|c|c|c|c|c|}
\hline \multicolumn{5}{|c|}{ Azara's agouti } & \multicolumn{4}{|c|}{ Collared peccary } & \multicolumn{4}{|c|}{ Brown brocket deer } & \multicolumn{4}{|c|}{ South American tapir } \\
\hline $\begin{array}{l}\text { Landscape } \\
\text { metric }\end{array}$ & $\begin{array}{l}\text { Buffer } \\
\text { size }\end{array}$ & Model structure & AIC & $\triangle \mathrm{AIC}$ & $\begin{array}{l}\text { Buffer } \\
\text { size }\end{array}$ & $\begin{array}{l}\text { Model } \\
\text { structure }\end{array}$ & AIC & $\triangle \mathrm{AIC}$ & $\begin{array}{l}\text { Buffer } \\
\text { size }\end{array}$ & $\begin{array}{l}\begin{array}{l}\text { Model } \\
\text { structure }\end{array} \\
\end{array}$ & AIC & $\triangle \mathrm{AIC}$ & $\begin{array}{l}\text { Buffer } \\
\text { size }\end{array}$ & Model structure & AIC & $\triangle \mathrm{AIC}$ \\
\hline \multirow{9}{*}{ ED } & Null & $\begin{array}{l}\text { p (weather + } \\
\text { visibility) } \Psi(1)\end{array}$ & 152.43 & 6.18 & Null & $\begin{array}{l}\mathrm{p} \text { (visibility) } \\
\Psi(1)\end{array}$ & 173.54 & 0.07 & Null & $\begin{array}{l}\text { p (visibility) } \\
\Psi(1)\end{array}$ & 145.56 & 0.16 & Null & $\begin{array}{l}\mathrm{p} \text { (weather }+ \\
\text { visibility) } \Psi(1)\end{array}$ & 231.04 & 0.00 \\
\hline & 500 & $\begin{array}{l}\mathrm{p} \text { (weather + } \\
\text { visibility) } \Psi(\mathrm{ED})\end{array}$ & 146.25 & 0.00 & 500 & $\begin{array}{l}\mathrm{p} \text { (visibility) } \\
\Psi(\mathrm{ED})\end{array}$ & 173.47 & 0.00 & 500 & $\begin{array}{l}\mathrm{p} \text { (visibility) } \\
\Psi(\mathrm{ED})\end{array}$ & 146.89 & 1.49 & 500 & $\begin{array}{l}\text { p (weather + } \\
\text { visibility) } \Psi(E D)\end{array}$ & 231.32 & 0.28 \\
\hline & 750 & $\begin{array}{l}\mathrm{p} \text { (weather + } \\
\text { visibility) } \Psi(\mathrm{ED})\end{array}$ & 148.06 & 1.80 & 750 & $\begin{array}{l}\text { p (visibility) } \\
\Psi(\mathrm{ED})\end{array}$ & 173.50 & 0.02 & 750 & $\begin{array}{l}\text { p (visibility) } \\
\Psi(\mathrm{ED})\end{array}$ & 145.73 & 0.33 & 750 & $\begin{array}{l}\mathrm{p} \text { (weather + } \\
\text { visibility) } \Psi(\mathrm{ED})\end{array}$ & 231.81 & 0.77 \\
\hline & 1000 & $\begin{array}{l}\mathrm{p} \text { (weather + } \\
\text { visibility) } \Psi(\mathrm{ED})\end{array}$ & 147.39 & 1.13 & 1000 & $\begin{array}{l}\text { p (visibility) } \\
\Psi(\text { ED) }\end{array}$ & 174.57 & 1.10 & 1000 & $\begin{array}{l}\mathrm{p} \text { (visibility) } \\
\Psi(\mathrm{ED})\end{array}$ & 145.40 & 0.00 & 1000 & $\begin{array}{l}\mathrm{p} \text { (weather + } \\
\text { visibility) } \Psi(\mathrm{ED})\end{array}$ & 232.27 & 1.23 \\
\hline & 1500 & $\begin{array}{l}\text { p (weather + } \\
\text { visibility) } \Psi(E D)\end{array}$ & 148.08 & 1.83 & 1500 & $\begin{array}{l}\mathrm{p} \text { (visibility) } \\
\Psi(\mathrm{ED})\end{array}$ & 174.77 & 1.30 & 1500 & $\begin{array}{l}\mathrm{p} \text { (visibility) } \\
\Psi(\mathrm{ED})\end{array}$ & 146.63 & 1.23 & 1500 & $\begin{array}{l}\text { p (weather + } \\
\text { visibility) } \Psi(E D)\end{array}$ & 232.93 & 1.89 \\
\hline & 2000 & $\begin{array}{l}\mathrm{p} \text { (weather + } \\
\text { visibility) } \Psi(\mathrm{ED})\end{array}$ & 149.63 & 3.38 & 2000 & $\begin{array}{l}\text { p (visibility) } \\
\Psi(\mathrm{ED})\end{array}$ & 174.61 & 1.13 & 2000 & $\begin{array}{l}\text { p (visibility) } \\
\Psi(\mathrm{ED})\end{array}$ & 147.12 & 1.72 & 2000 & $\begin{array}{l}\mathrm{p} \text { (weather + } \\
\text { visibility) } \Psi(\mathrm{ED})\end{array}$ & 233.04 & 2.00 \\
\hline & 3000 & $\begin{array}{l}\mathrm{p} \text { (weather + } \\
\text { visibility) } \Psi(\mathrm{ED})\end{array}$ & 152.34 & 6.09 & 3000 & $\begin{array}{l}\mathrm{p} \text { (visibility) } \\
\Psi(\mathrm{ED})\end{array}$ & 174.91 & 1.44 & 3000 & $\begin{array}{l}\text { p (visibility) } \\
\Psi(E D)\end{array}$ & 147.10 & 1.70 & 3000 & $\begin{array}{l}\text { p (weather + } \\
\text { visibility) } \Psi(E D)\end{array}$ & 232.99 & 1.95 \\
\hline & 5000 & $\begin{array}{l}\text { p (weather + } \\
\text { visibility) } \Psi(E D)\end{array}$ & 154.12 & 7.87 & 5000 & $\begin{array}{l}p \text { (visibility) } \\
\Psi(E D)\end{array}$ & 175.22 & 1.75 & 5000 & $\begin{array}{l}\mathrm{p} \text { (visibility) } \\
\Psi(\mathrm{ED})\end{array}$ & 146.38 & 0.98 & 5000 & $\begin{array}{l}\text { p (weather + } \\
\text { visibility) } \Psi(E D)\end{array}$ & 233.04 & 2.00 \\
\hline & 10000 & $\begin{array}{l}\text { p (weather }+ \\
\text { visibility) } \Psi(E D)\end{array}$ & 154.13 & 7.88 & 10000 & $\begin{array}{l}\mathrm{p} \text { (visibility) } \\
\Psi(\mathrm{ED})\end{array}$ & 175.28 & 1.81 & 10000 & $\begin{array}{l}\text { p (visibility) } \\
\Psi(E D)\end{array}$ & 145.88 & 0.47 & 10000 & $\begin{array}{l}\text { p (weather + } \\
\text { visibility) } \Psi(E D)\end{array}$ & 233.04 & 2.00 \\
\hline \multirow{9}{*}{ PD } & Null & $\begin{array}{l}\text { p (weather + } \\
\text { visibility) } \Psi(1)\end{array}$ & 152.43 & 0.00 & Null & $\begin{array}{l}\mathrm{p} \text { (visibility) } \\
\Psi(1)\end{array}$ & 173.54 & 0.00 & Null & $\begin{array}{l}\mathrm{p} \text { (visibility) } \\
\Psi(1)\end{array}$ & 145.56 & 6.13 & Null & $\begin{array}{l}\mathrm{p} \text { (weather + } \\
\text { visibility) } \Psi(1)\end{array}$ & 231.04 & 0.00 \\
\hline & 500 & $\begin{array}{l}\text { p (weather + } \\
\text { visibility) } \Psi(\mathrm{PD})\end{array}$ & 152.98 & 0.54 & 500 & $\begin{array}{l}\mathrm{p} \text { (visibility) } \\
\Psi(\mathrm{PD})\end{array}$ & 175.49 & 1.95 & 500 & $\begin{array}{l}\mathrm{p} \text { (visibility) } \\
\Psi(\mathrm{PD})\end{array}$ & 143.78 & 4.35 & 500 & $\begin{array}{l}\text { p (weather + } \\
\text { visibility) } \Psi(\mathrm{PD})\end{array}$ & 232.63 & 1.59 \\
\hline & 750 & $\begin{array}{l}\text { p (weather + } \\
\text { visibility) } \Psi(\mathrm{PD})\end{array}$ & 154.40 & 1.97 & 750 & $\begin{array}{l}\mathrm{p} \text { (visibility) } \\
\Psi(\mathrm{PD})\end{array}$ & 175.46 & 1.91 & 750 & $\begin{array}{l}\text { p (visibility) } \\
\Psi(\mathrm{PD})\end{array}$ & 139.42 & 0.00 & 750 & $\begin{array}{l}\text { p (weather + } \\
\text { visibility) } \Psi(\mathrm{PD})\end{array}$ & 232.60 & 1.56 \\
\hline & 1000 & $\begin{array}{l}\text { p (weather + } \\
\text { visibility) } \Psi(\mathrm{PD})\end{array}$ & 154.43 & 2.00 & 1000 & $\begin{array}{l}\mathrm{p} \text { (visibility) } \\
\Psi(\mathrm{PD})\end{array}$ & 175.15 & 1.61 & 1000 & $\begin{array}{l}\mathrm{p} \text { (visibility) } \\
\Psi(\mathrm{PD})\end{array}$ & 143.41 & 3.99 & 1000 & $\begin{array}{l}\text { p (weather + } \\
\text { visibility) } \Psi(\mathrm{PD})\end{array}$ & 232.98 & 1.94 \\
\hline & 1500 & $\begin{array}{l}\text { p (weather + } \\
\text { visibility) } \Psi(\mathrm{PD})\end{array}$ & 153.93 & 1.50 & 1500 & $\begin{array}{l}\mathrm{p} \text { (visibility) } \\
\Psi(\mathrm{PD})\end{array}$ & 175.49 & 1.94 & 1500 & $\begin{array}{l}\mathrm{p} \text { (visibility) } \\
\Psi(\mathrm{PD})\end{array}$ & 145.92 & 6.49 & 1500 & $\begin{array}{l}\mathrm{p} \text { (weather + } \\
\text { visibility) } \Psi(\mathrm{PD})\end{array}$ & 232.67 & 1.63 \\
\hline & 2000 & $\begin{array}{l}\text { p (weather + } \\
\text { visibility) } \Psi(\mathrm{PD})\end{array}$ & 154.15 & 1.71 & 2000 & $\begin{array}{l}\mathrm{p} \text { (visibility) } \\
\Psi(\mathrm{PD})\end{array}$ & 175.52 & 1.98 & 2000 & $\begin{array}{l}\mathrm{p} \text { (visibility) } \\
\Psi(\mathrm{PD})\end{array}$ & 145.54 & 6.12 & 2000 & $\begin{array}{l}\text { p (weather + } \\
\text { visibility) } \Psi(\mathrm{PD})\end{array}$ & 233.04 & 2.00 \\
\hline & 3000 & $\begin{array}{l}\text { p (weather + } \\
\text { visibility) } \Psi(\mathrm{PD})\end{array}$ & 154.12 & 1.69 & 3000 & $\begin{array}{l}\mathrm{p} \text { (visibility) } \\
\Psi(\mathrm{PD})\end{array}$ & 175.48 & 1.93 & 3000 & $\begin{array}{l}\mathrm{p} \text { (visibility) } \\
\Psi(\mathrm{PD})\end{array}$ & 144.53 & 5.11 & 3000 & $\begin{array}{l}\text { p (weather + } \\
\text { visibility) } \Psi(\mathrm{PD})\end{array}$ & 233.04 & 1.99 \\
\hline & 5000 & $\begin{array}{l}\text { p (weather + } \\
\text { visibility) } \Psi(\mathrm{PD})\end{array}$ & 154.43 & 2.00 & 5000 & $\begin{array}{l}\mathrm{p} \text { (visibility) } \\
\Psi(\mathrm{PD})\end{array}$ & 175.54 & 2.00 & 5000 & $\begin{array}{l}\mathrm{p} \text { (visibility) } \\
\Psi(\mathrm{PD})\end{array}$ & 144.66 & 5.24 & 5000 & $\begin{array}{l}\text { p (weather + } \\
\text { visibility) } \Psi(\mathrm{PD})\end{array}$ & 232.85 & 1.81 \\
\hline & 10000 & $\begin{array}{l}\mathrm{p} \text { (weather }+ \\
\text { visibility) } \Psi(\mathrm{PD})\end{array}$ & 154.43 & 2.00 & 10000 & $\begin{array}{l}\text { p (visibility) } \\
\Psi(P D)\end{array}$ & 174.55 & 1.01 & 10000 & $\begin{array}{l}\mathrm{p} \text { (visibility) } \\
\Psi(\mathrm{PD})\end{array}$ & 145.46 & 6.03 & 10000 & $\begin{array}{l}\mathrm{p} \text { (weather + } \\
\text { visibility) } \Psi(\mathrm{PD})\end{array}$ & 231.77 & 0.73 \\
\hline \multirow{9}{*}{ FC } & Null & $\begin{array}{l}\mathrm{p} \text { (weather + } \\
\text { visibility) } \Psi(1)\end{array}$ & 152.43 & 3.07 & Null & $\begin{array}{l}\mathrm{p} \text { (visibility) } \\
\Psi(1)\end{array}$ & 173.54 & 4.84 & Null & $\begin{array}{l}\text { p (visibility) } \\
\Psi(1)\end{array}$ & 145.56 & 0.00 & Null & $\begin{array}{l}\text { p (weather + } \\
\text { visibility) } \Psi(1)\end{array}$ & 231.04 & 0.89 \\
\hline & 500 & $\begin{array}{l}\mathrm{p} \text { (weather + } \\
\text { visibility) } \Psi(\mathrm{FC})\end{array}$ & 150.83 & 1.46 & 500 & $\begin{array}{l}\text { p (visibility) } \\
\Psi(\mathrm{FC})\end{array}$ & 168.70 & 0.00 & 500 & $\begin{array}{l}\text { p (visibility) } \\
\Psi(\mathrm{FC})\end{array}$ & 146.33 & 0.77 & 500 & $\begin{array}{l}\mathrm{p} \text { (weather + } \\
\text { visibility) } \Psi(\mathrm{FC})\end{array}$ & 230.15 & 0.00 \\
\hline & 750 & $\begin{array}{l}\mathrm{p} \text { (weather + } \\
\text { visibility) } \Psi(\mathrm{FC})\end{array}$ & 150.40 & 1.03 & 750 & $\begin{array}{l}\text { p (visibility) } \\
\Psi(\mathrm{FC})\end{array}$ & 170.20 & 1.49 & 750 & $\begin{array}{l}\text { p (visibility) } \\
\Psi(\mathrm{FC})\end{array}$ & 146.16 & 0.60 & 750 & $\begin{array}{l}\mathrm{p} \text { (weather + } \\
\text { visibility) } \Psi(\mathrm{FC})\end{array}$ & 231.54 & 1.39 \\
\hline & 1000 & $\begin{array}{l}\mathrm{p} \text { (weather + } \\
\text { visibility) } \Psi(\mathrm{FC})\end{array}$ & 149.66 & 0.30 & 1000 & $\begin{array}{l}\text { p (visibility) } \\
\Psi(\mathrm{FC})\end{array}$ & 171.50 & 2.80 & 1000 & $\begin{array}{l}\text { p (visibility) } \\
\Psi(\text { FC) }\end{array}$ & 146.13 & 0.57 & 1000 & $\begin{array}{l}\mathrm{p} \text { (weather + } \\
\text { visibility) } \Psi(\mathrm{FC})\end{array}$ & 231.71 & 1.56 \\
\hline & 1500 & $\begin{array}{l}\text { p (weather + } \\
\text { visibility) } \Psi(\mathrm{FC})\end{array}$ & 149.37 & 0.00 & 1500 & $\begin{array}{l}\mathrm{p} \text { (visibility) } \\
\Psi(\mathrm{FC})\end{array}$ & 172.83 & 4.13 & 1500 & $\begin{array}{l}\text { p (visibility) } \\
\Psi(\text { FC) }\end{array}$ & 146.21 & 0.65 & 1500 & $\begin{array}{l}\text { p (weather + } \\
\text { visibility) } \Psi(\mathrm{FC})\end{array}$ & 232.44 & 2.28 \\
\hline & 2000 & $\begin{array}{l}\text { p (weather }+ \\
\text { visibility) } \Psi(F C)\end{array}$ & 149.87 & 0.50 & 2000 & $\begin{array}{l}\mathrm{p} \text { (visibility) } \\
\Psi(\mathrm{FC})\end{array}$ & 173.92 & 5.22 & 2000 & $\begin{array}{l}\mathrm{p} \text { (visibility) } \\
\Psi(\mathrm{FC})\end{array}$ & 146.97 & 1.41 & 2000 & $\begin{array}{l}\text { p (weather + } \\
\text { visibility) } \Psi(F C)\end{array}$ & 232.88 & 2.73 \\
\hline & 3000 & $\begin{array}{l}\mathrm{p} \text { (weather }+ \\
\text { visibility) } \Psi(\mathrm{FC})\end{array}$ & 152.37 & 3.00 & 3000 & $\begin{array}{l}\text { p (visibility) } \\
\Psi(\mathrm{FC})\end{array}$ & 174.83 & 6.13 & 3000 & $\begin{array}{l}\mathrm{p} \text { (visibility) } \\
\Psi(\mathrm{FC})\end{array}$ & 147.06 & 1.51 & 3000 & $\begin{array}{l}\mathrm{p} \text { (weather + } \\
\text { visibility) } \Psi(\mathrm{FC})\end{array}$ & 233.02 & 2.87 \\
\hline & 5000 & $\begin{array}{l}\mathrm{p} \text { (weather + } \\
\text { visibility) } \Psi(\mathrm{FC})\end{array}$ & 153.60 & 4.23 & 5000 & $\begin{array}{l}\text { p (visibility) } \\
\Psi(\mathrm{FC})\end{array}$ & 175.41 & 6.71 & 5000 & $\begin{array}{l}\text { p (visibility) } \\
\Psi(\text { FC) }\end{array}$ & 147.29 & 1.73 & 5000 & $\begin{array}{l}\mathrm{p} \text { (weather + } \\
\text { visibility) } \Psi(\mathrm{FC})\end{array}$ & 232.94 & 2.79 \\
\hline & 10000 & $\begin{array}{l}\mathrm{p} \text { (weather + } \\
\text { visibility) } \Psi(\mathrm{FC})\end{array}$ & 153.97 & 4.61 & 10000 & $\begin{array}{l}\text { p (visibility) } \\
\Psi(\text { FC) }\end{array}$ & 175.52 & 6.82 & 10000 & $\begin{array}{l}\text { p (visibility) } \\
\Psi(\text { FC) }\end{array}$ & 147.16 & 1.60 & 10000 & $\begin{array}{l}\mathrm{p} \text { (weather + } \\
\text { visibility) } \Psi(\mathrm{FC})\end{array}$ & 232.87 & 2.72 \\
\hline
\end{tabular}


702 Table S3. Performance of occupancy models predicting the occurrence of four species of terrestrial 703 mammals (Azara's agouti Dasyprocta azarae, collared peccary Pecari tajacu, brown brocket deer 704 Mazama gouazoubira, and South American tapir Tapirus terrestris, ) in the Brazilian Cerrado 705 hotspot across buffer size (from 500 to $10000 \mathrm{~m}$ ) considering $50 \%$ as the threshold of tree cover. 706 Model structure mentions how occupancy probability $\Psi$ at the camera trap i and the detection 707 probability p were implemented. Analyses were carried out separately for each species and 708 landscape metric including edge density, ED, patch density, PD, and the percentage of forest cover, 709 FC. Buffer size is indicated in $\mathrm{m}$. AIC is the Akaike criterion. Models of similar statistical supports 710 with $\triangle \mathrm{AIC}<2$ from the minimum model are in bold.

711

\begin{tabular}{|c|c|c|c|c|c|c|c|c|c|c|c|c|c|c|c|c|}
\hline \multicolumn{5}{|c|}{ Azara's agouti } & \multicolumn{4}{|c|}{ Collared peccary } & \multicolumn{4}{|c|}{ Brown brocket deer } & \multicolumn{4}{|c|}{ South American tapir } \\
\hline $\begin{array}{l}\text { Landscape } \\
\text { metric }\end{array}$ & $\begin{array}{l}\text { Buffer } \\
\text { size }\end{array}$ & Model structure & AIC & $\triangle \mathrm{AIC}$ & $\begin{array}{l}\text { Buffer } \\
\text { size }\end{array}$ & $\begin{array}{l}\text { Model } \\
\text { structure }\end{array}$ & AIC & $\triangle \mathrm{AIC}$ & $\begin{array}{l}\text { Buffer } \\
\text { size }\end{array}$ & $\begin{array}{l}\text { Model } \\
\text { structure }\end{array}$ & AIC & $\triangle \mathrm{AIC}$ & $\begin{array}{l}\text { Buffer } \\
\text { size }\end{array}$ & Model structure & AIC & $\triangle \mathrm{AIC}$ \\
\hline \multirow{9}{*}{ ED } & Null & $\begin{array}{l}\text { p (weather + } \\
\text { visibility) } \Psi(1) \\
\text { p (weather + }\end{array}$ & 152.43 & 2.89 & Null & $\begin{array}{l}\mathrm{p} \text { (visibility) } \\
\Psi(1) \\
\mathrm{p} \text { (visibility) }\end{array}$ & 173.54 & 0.00 & Null & $\begin{array}{l}\mathrm{p} \text { (visibility) } \\
\Psi(1) \\
\mathrm{p} \text { (visibility) }\end{array}$ & 145.56 & 1.43 & Null & $\begin{array}{l}\text { p (weather + } \\
\text { visibility) } \Psi(1) \\
\text { p (weather + }\end{array}$ & 231.04 & 0.00 \\
\hline & 500 & $\begin{array}{l}\text { visibility) } \Psi(E D) \\
\text { p (weather + }\end{array}$ & 149.54 & 0.00 & 500 & $\begin{array}{l}\Psi(E D) \\
\text { p (visibility) }\end{array}$ & 175.12 & 1.58 & 500 & $\begin{array}{l}\Psi(E D) \\
\text { p (visibility) }\end{array}$ & 145.48 & 1.35 & 500 & $\begin{array}{l}\text { visibility) } \Psi(E D) \\
\text { p (weather + }\end{array}$ & 232.32 & 1.27 \\
\hline & 750 & $\begin{array}{l}\text { visibility) } \Psi(E D) \\
\text { p (weather + }\end{array}$ & 151.63 & 2.08 & 750 & $\begin{array}{l}\Psi(\mathrm{ED}) \\
\mathrm{p} \text { (visibility) }\end{array}$ & 175.08 & 1.54 & 750 & $\begin{array}{l}\Psi(\text { (ED) } \\
\text { p (visibility) }\end{array}$ & 144.80 & 0.67 & 750 & $\begin{array}{l}\text { visibility) } \Psi(\mathrm{ED}) \\
\text { p (weather + }\end{array}$ & 232.29 & 1.25 \\
\hline & 1000 & $\begin{array}{l}\text { visibility) } \Psi(E D) \\
\text { p (weather + }\end{array}$ & 152.15 & 2.61 & 1000 & $\begin{array}{l}\Psi(E D) \\
\text { p (visibility) }\end{array}$ & 175.53 & 1.98 & 1000 & $\begin{array}{l}\Psi(\mathrm{ED}) \\
\mathrm{p} \text { (visibility) }\end{array}$ & 144.50 & 0.37 & 1000 & $\begin{array}{l}\text { visibility) } \Psi(E D) \\
\text { p (weather + }\end{array}$ & 232.89 & 1.85 \\
\hline & 1500 & $\begin{array}{l}\text { visibility) } \Psi(E D) \\
\text { p (weather + }\end{array}$ & 151.83 & 2.29 & 1500 & $\begin{array}{l}\Psi(\text { ED) } \\
\text { p (visibility) }\end{array}$ & 175.51 & 1.97 & 1500 & $\begin{array}{l}\Psi(\mathrm{ED}) \\
\mathrm{p} \text { (visibility) }\end{array}$ & 145.58 & 1.44 & 1500 & $\begin{array}{l}\text { visibility) } \Psi(E D) \\
\text { p (weather + }\end{array}$ & 233.00 & 1.95 \\
\hline & 2000 & $\begin{array}{l}\text { visibility) } \Psi(\mathrm{ED}) \\
\text { p (weather + }\end{array}$ & 152.35 & 2.80 & 2000 & $\begin{array}{l}\Psi(\text { ED) } \\
\text { p (visibility) }\end{array}$ & 175.30 & 1.76 & 2000 & $\begin{array}{l}\Psi(\text { ED) } \\
\text { p (visibility) }\end{array}$ & 146.10 & 1.97 & 2000 & $\begin{array}{l}\text { visibility) } \Psi(E D) \\
\text { p (weather + }\end{array}$ & 233.04 & 2.00 \\
\hline & 3000 & $\begin{array}{l}\text { visibility) } \Psi(E D) \\
\text { p (weather + }\end{array}$ & 153.49 & 3.95 & 3000 & $\begin{array}{l}\Psi(E D) \\
\text { p (visibility) }\end{array}$ & 175.43 & 1.89 & 3000 & $\begin{array}{l}\Psi(\text { ED) } \\
\text { p (visibility) }\end{array}$ & 145.26 & 1.13 & 3000 & $\begin{array}{l}\text { visibility) } \Psi(E D) \\
\text { p (weather + }\end{array}$ & 232.96 & 1.92 \\
\hline & 5000 & $\begin{array}{l}\text { visibility) } \Psi(E D) \\
\text { p (weather + }\end{array}$ & 154.09 & 4.55 & 5000 & $\begin{array}{l}\Psi(\mathrm{ED}) \\
\mathrm{p} \text { (visibility) }\end{array}$ & 175.43 & 1.89 & 5000 & $\begin{array}{l}\Psi(\mathrm{ED}) \\
\mathrm{p} \text { (visibility) }\end{array}$ & 144.87 & 0.74 & 5000 & $\begin{array}{l}\text { visibility) } \Psi(E D) \\
\text { p (weather + }\end{array}$ & 233.00 & 1.96 \\
\hline & 10000 & visibility) $\Psi(E D)$ & 154.25 & 4.71 & 10000 & $\Psi(\mathrm{ED})$ & 175.18 & 1.64 & 10000 & $\Psi(\mathrm{ED})$ & 144.13 & 0.00 & 10000 & visibility) $\Psi(E D)$ & 232.41 & 1.37 \\
\hline \multirow{9}{*}{ PD } & Null & $\begin{array}{l}\mathrm{p} \text { (weather + } \\
\text { visibility) } \Psi(1) \\
\text { p (weather + }\end{array}$ & 152.43 & 2.05 & Null & $\begin{array}{l}\mathrm{p} \text { (visibility) } \\
\Psi(1) \\
\mathrm{p} \text { (visibility) }\end{array}$ & 173.54 & 0.00 & Null & $\begin{array}{l}\mathrm{p} \text { (visibility) } \\
\Psi(1) \\
\text { p (visibility) }\end{array}$ & 145.56 & 1.83 & Null & $\begin{array}{l}\text { p (weather + } \\
\text { visibility) } \Psi(1) \\
\text { p (weather + }\end{array}$ & 231.04 & 0.00 \\
\hline & 500 & $\begin{array}{l}\text { visibility) } \Psi(\mathrm{PD}) \\
\mathrm{p} \text { (weather + }\end{array}$ & 154.27 & 3.88 & 500 & $\begin{array}{l}\Psi(\mathrm{PD}) \\
\mathrm{p} \text { (visibility) }\end{array}$ & 175.43 & 1.88 & 500 & $\begin{array}{l}\Psi(\mathrm{PD}) \\
\mathrm{p} \text { (visibility) }\end{array}$ & 143.73 & 0.00 & 500 & $\begin{array}{l}\text { visibility) } \Psi(\mathrm{PD}) \\
\mathrm{p} \text { (weather + }\end{array}$ & 233.03 & 1.99 \\
\hline & 750 & $\begin{array}{l}\text { visibility) } \Psi(\mathrm{PD}) \\
\mathrm{p} \text { (weather + }\end{array}$ & 153.96 & 3.58 & 750 & $\begin{array}{l}\Psi(\mathrm{PD}) \\
\mathrm{p} \text { (visibility) }\end{array}$ & 174.24 & 0.70 & 750 & $\begin{array}{l}\Psi(\mathrm{PD}) \\
\mathrm{p} \text { (visibility) }\end{array}$ & 144.95 & 1.22 & 750 & $\begin{array}{l}\text { visibility) } \Psi(\mathrm{PD}) \\
\mathrm{p} \text { (weather + }\end{array}$ & 233.01 & 1.97 \\
\hline & 1000 & $\begin{array}{l}\text { visibility) } \Psi(\mathrm{PD}) \\
\text { p (weather + }\end{array}$ & 152.87 & 2.49 & 1000 & $\begin{array}{l}\Psi(\mathrm{PD}) \\
\text { p (visibility) }\end{array}$ & 174.45 & 0.91 & 1000 & $\begin{array}{l}\Psi(\mathrm{PD}) \\
\text { p (visibility) }\end{array}$ & 146.62 & 2.89 & 1000 & $\begin{array}{l}\text { visibility) } \Psi(\mathrm{PD}) \\
\text { p (weather + }\end{array}$ & 232.17 & 1.12 \\
\hline & 1500 & $\begin{array}{l}\text { visibility) } \Psi(\mathrm{PD}) \\
\text { p (weather + }\end{array}$ & 152.24 & 1.85 & 1500 & $\begin{array}{l}\Psi(\mathrm{PD}) \\
\mathrm{p} \text { (visibility) }\end{array}$ & 174.35 & 0.80 & 1500 & $\begin{array}{l}\Psi(\mathrm{PD}) \\
\mathrm{p} \text { (visibility) }\end{array}$ & 147.06 & 3.33 & 1500 & $\begin{array}{l}\text { visibility) } \Psi(\mathrm{PD}) \\
\text { p (weather + }\end{array}$ & 232.55 & 1.51 \\
\hline & 2000 & $\begin{array}{l}\text { visibility) } \Psi(\mathrm{PD}) \\
\mathrm{p} \text { (weather + }\end{array}$ & 150.38 & 0.00 & 2000 & $\begin{array}{l}\Psi(\mathrm{PD}) \\
\mathrm{p} \text { (visibility) }\end{array}$ & 175.07 & 1.53 & 2000 & $\begin{array}{l}\Psi(\mathrm{PD}) \\
\mathrm{p} \text { (visibility) }\end{array}$ & 146.83 & 3.10 & 2000 & $\begin{array}{l}\text { visibility) } \Psi(\mathrm{PD}) \\
\mathrm{p} \text { (weather + }\end{array}$ & 233.04 & 2.00 \\
\hline & 3000 & $\begin{array}{l}\text { visibility) } \Psi(\mathrm{PD}) \\
\text { p (weather + }\end{array}$ & 151.52 & 1.13 & 3000 & $\begin{array}{l}\Psi(\mathrm{PD}) \\
\mathrm{p} \text { (visibility) }\end{array}$ & 175.35 & 1.81 & 3000 & $\begin{array}{l}\Psi(\mathrm{PD}) \\
\mathrm{p} \text { (visibility) }\end{array}$ & 146.92 & 3.19 & 3000 & $\begin{array}{l}\text { visibility) } \Psi(\mathrm{PD}) \\
\mathrm{p} \text { (weather + }\end{array}$ & 232.87 & 1.83 \\
\hline & 5000 & $\begin{array}{l}\text { visibility) } \Psi(\mathrm{PD}) \\
\text { p (weather + }\end{array}$ & 153.40 & 3.01 & 5000 & $\begin{array}{l}\Psi(\mathrm{PD}) \\
\mathrm{p} \text { (visibility) }\end{array}$ & 175.30 & 1.75 & 5000 & $\begin{array}{l}\Psi(\mathrm{PD}) \\
\mathrm{p} \text { (visibility) }\end{array}$ & 146.28 & 2.55 & 5000 & $\begin{array}{l}\text { visibility) } \Psi(\mathrm{PD}) \\
\mathrm{p} \text { (weather + }\end{array}$ & 232.75 & 1.71 \\
\hline & 10000 & visibility) $\Psi(\mathrm{PD})$ & 153.43 & 3.05 & 10000 & $\Psi(\mathrm{PD})$ & 175.54 & 2.00 & 10000 & $\Psi(\mathrm{PD})$ & 147.44 & 3.71 & 10000 & visibility) $\Psi(\mathrm{PD})$ & 231.83 & 0.79 \\
\hline \multirow{9}{*}{$\mathrm{FC}$} & Null & $\begin{array}{l}\mathrm{p} \text { (weather + } \\
\text { visibility) } \Psi(1) \\
\mathrm{p} \text { (weather + }\end{array}$ & 152.43 & 3.28 & Null & $\begin{array}{l}\mathrm{p} \text { (visibility) } \\
\Psi(1) \\
\mathrm{p} \text { (visibility) }\end{array}$ & 173.54 & 3.45 & Null & $\begin{array}{l}\mathrm{p} \text { (visibility) } \\
\Psi(1) \\
\mathrm{p} \text { (visibility) }\end{array}$ & 145.56 & 0.00 & Null & $\begin{array}{l}\mathrm{p} \text { (weather + } \\
\text { visibility) } \Psi(1) \\
\mathrm{p} \text { (weather + }\end{array}$ & 231.04 & 0.41 \\
\hline & 500 & $\begin{array}{l}\text { visibility) } \Psi(\mathrm{FC}) \\
\text { p (weather + }\end{array}$ & 149.15 & 0.00 & 500 & $\begin{array}{l}\Psi(\mathrm{FC}) \\
\mathrm{p} \text { (visibility) }\end{array}$ & 170.09 & 0.00 & 500 & $\begin{array}{l}\Psi(\mathrm{FC}) \\
\mathrm{p} \text { (visibility) }\end{array}$ & 145.80 & 0.25 & 500 & $\begin{array}{l}\text { visibility) } \Psi(\mathrm{FC}) \\
\text { p (weather + }\end{array}$ & 230.63 & 0.00 \\
\hline & 750 & $\begin{array}{l}\text { visibility) } \Psi(\mathrm{FC}) \\
\text { p (weather + }\end{array}$ & 150.26 & 1.11 & 750 & $\begin{array}{l}\Psi(\mathrm{FC}) \\
\text { p (visibility) }\end{array}$ & 170.80 & 0.71 & 750 & $\begin{array}{l}\Psi(\mathrm{FC}) \\
\text { p (visibility) }\end{array}$ & 145.68 & 0.12 & 750 & $\begin{array}{l}\text { visibility) } \Psi(\mathrm{FC}) \\
\mathrm{p} \text { (weather + }\end{array}$ & 231.54 & 0.91 \\
\hline & 1000 & $\begin{array}{l}\text { visibility) } \Psi(\mathrm{FC}) \\
\mathrm{p} \text { (weather + }\end{array}$ & 149.31 & 0.16 & 1000 & $\begin{array}{l}\Psi(\mathrm{FC}) \\
\mathrm{p} \text { (visibility) }\end{array}$ & 171.95 & 1.86 & 1000 & $\begin{array}{l}\Psi(\mathrm{FC}) \\
\mathrm{p} \text { (visibility) }\end{array}$ & 145.82 & 0.26 & 1000 & $\begin{array}{l}\text { visibility) } \Psi(\mathrm{FC}) \\
\mathrm{p} \text { (weather + }\end{array}$ & 231.88 & 1.25 \\
\hline & 1500 & $\begin{array}{l}\text { visibility) } \Psi(\mathrm{FC}) \\
\text { p (weather + }\end{array}$ & 149.44 & 0.29 & 1500 & $\begin{array}{l}\Psi(\mathrm{FC}) \\
\mathrm{p} \text { (visibility) }\end{array}$ & 173.02 & 2.93 & 1500 & $\begin{array}{l}\Psi(\mathrm{FC}) \\
\mathrm{p} \text { (visibility) }\end{array}$ & 145.79 & 0.23 & 1500 & $\begin{array}{l}\text { visibility) } \Psi(\mathrm{FC}) \\
\text { p (weather + }\end{array}$ & 232.60 & 1.97 \\
\hline & 2000 & $\begin{array}{l}\text { visibility) } \Psi(\mathrm{FC}) \\
\mathrm{p} \text { (weather + }\end{array}$ & 150.31 & 1.16 & 2000 & $\begin{array}{l}\Psi(\mathrm{FC}) \\
\mathrm{p} \text { (visibility) }\end{array}$ & 173.87 & 3.78 & 2000 & $\begin{array}{l}\Psi(F C) \\
\text { p (visibility) }\end{array}$ & 146.62 & 1.07 & 2000 & $\begin{array}{l}\text { visibility) } \Psi(\mathrm{FC}) \\
\mathrm{p} \text { (weather + }\end{array}$ & 232.95 & 2.31 \\
\hline & 3000 & $\begin{array}{l}\text { visibility) } \Psi(\mathrm{FC}) \\
\mathrm{p} \text { (weather + }\end{array}$ & 152.47 & 3.32 & 3000 & $\begin{array}{l}\Psi(\mathrm{FC}) \\
\mathrm{p} \text { (visibility) }\end{array}$ & 174.78 & 4.69 & 3000 & $\begin{array}{l}\Psi(\mathrm{FC}) \\
\mathrm{p} \text { (visibility) }\end{array}$ & 146.72 & 1.17 & 3000 & $\begin{array}{l}\text { visibility) } \Psi(\mathrm{FC}) \\
\mathrm{p} \text { (weather + }\end{array}$ & 233.02 & 2.38 \\
\hline & 5000 & $\begin{array}{l}\text { visibility) } \Psi(\mathrm{FC}) \\
\mathrm{p} \text { (weather + }\end{array}$ & 153.63 & 4.48 & 5000 & $\begin{array}{l}\Psi(\mathrm{FC}) \\
\text { p (visibility) }\end{array}$ & 175.39 & 5.31 & 5000 & $\begin{array}{l}\Psi(\mathrm{FC}) \\
\mathrm{p} \text { (visibility) }\end{array}$ & 146.99 & 1.44 & 5000 & $\begin{array}{l}\text { visibility) } \Psi(F C) \\
\text { p (weather + }\end{array}$ & 232.95 & 2.32 \\
\hline & 10000 & visibility) $\Psi(\mathrm{FC})$ & 154.00 & 4.85 & 10000 & $\Psi(\mathrm{FC})$ & 175.50 & 5.42 & 10000 & $\Psi(\mathrm{FC})$ & 146.96 & 1.40 & 10000 & visibility) $\Psi(\mathrm{FC})$ & 232.88 & 2.25 \\
\hline
\end{tabular}


715 Table S4. Performance of occupancy models predicting the occurrence of four species of terrestrial 716 mammals (Azara's agouti Dasyprocta azarae, collared peccary Pecari tajacu, brown brocket deer 717 Mazama gouazoubira, and South American tapir Tapirus terrestris, ) in the Brazilian Cerrado 718 hotspot across buffer size (from 500 to $10000 \mathrm{~m}$ ) considering $25 \%$ as the threshold of tree cover. 719 Model structure mentions how occupancy probability $\Psi$ at the camera trap $i$ and the detection 720 probability $\mathrm{p}$ were implemented. Analyses were carried out separately for each species and 721 landscape metric including edge density, ED, patch density, PD, and the percentage of forest cover, 722 FC. Buffer size is indicated in m. AIC is the Akaike criterion. Models of similar statistical supports 723 with $\triangle \mathrm{AIC}<2$ from the minimum model are in bold.

724

\begin{tabular}{|c|c|c|c|c|c|c|c|c|c|c|c|c|c|c|c|c|}
\hline \multicolumn{5}{|c|}{ Azara's agouti } & \multicolumn{4}{|c|}{ Collared peccary } & \multicolumn{4}{|c|}{ Brown brocket deer } & \multicolumn{4}{|c|}{ South American tapir } \\
\hline $\begin{array}{l}\text { Landscape } \\
\text { metric }\end{array}$ & $\begin{array}{l}\text { Buffer } \\
\text { size }\end{array}$ & Model structure & AIC & $\triangle \mathrm{AIC}$ & $\begin{array}{l}\text { Buffer } \\
\text { size }\end{array}$ & $\begin{array}{l}\begin{array}{l}\text { Model } \\
\text { structure }\end{array} \\
\end{array}$ & AIC & $\triangle \mathrm{AIC}$ & $\begin{array}{l}\begin{array}{l}\text { Buffer } \\
\text { size }\end{array} \\
\end{array}$ & $\begin{array}{l}\begin{array}{l}\text { Model } \\
\text { structure }\end{array} \\
\end{array}$ & AIC & $\Delta \mathrm{AIC}$ & $\begin{array}{l}\text { Buffer } \\
\text { size }\end{array}$ & Model structure & AIC & $\triangle \mathrm{AIC}$ \\
\hline \multirow{9}{*}{ ED } & Null & $\begin{array}{l}\mathrm{p} \text { (weather + } \\
\text { visibility) }(1) \\
\text { p (weather + }\end{array}$ & 152.43 & 0.87 & Null & $\begin{array}{l}\mathrm{p} \text { (visibility) } \\
\Psi(1) \\
\mathrm{p} \text { (visibility) }\end{array}$ & 173.54 & 0.00 & Null & $\begin{array}{l}\mathrm{p} \text { (visibility) } \\
\Psi(1) \\
\mathrm{p} \text { (visibility) }\end{array}$ & 145.56 & 1.92 & Null & $\begin{array}{l}\mathrm{p} \text { (weather + } \\
\text { visibility) } \Psi(1) \\
\mathrm{p} \text { (weather + }\end{array}$ & 231.04 & 0.00 \\
\hline & 500 & $\begin{array}{l}\text { visibility) } \Psi(E D) \\
\text { p (weather + }\end{array}$ & 151.57 & 0.00 & 500 & $\begin{array}{l}\Psi(E D) \\
\text { p (visibility) }\end{array}$ & 175.50 & 1.96 & 500 & $\begin{array}{l}\Psi(E D) \\
\mathrm{p} \text { (visibility) }\end{array}$ & 145.42 & 1.78 & 500 & $\begin{array}{l}\text { visibility) } \Psi(E D) \\
\text { p (weather + }\end{array}$ & 232.87 & 1.83 \\
\hline & 750 & $\begin{array}{l}\text { visibility) } \Psi(E D) \\
\text { p (weather + }\end{array}$ & 152.81 & 1.24 & 750 & $\begin{array}{l}\Psi(E D) \\
\mathrm{p} \text { (visibility) }\end{array}$ & 175.54 & 1.99 & 750 & $\begin{array}{l}\Psi(\text { ED) } \\
\mathrm{p} \text { (visibility) }\end{array}$ & 143.64 & 0.00 & 750 & $\begin{array}{l}\text { visibility) } \Psi(E D) \\
\text { p (weather + }\end{array}$ & 232.79 & 1.75 \\
\hline & 1000 & $\begin{array}{l}\text { visibility) } \Psi(E D) \\
\text { p (weather + }\end{array}$ & 153.75 & 2.18 & 1000 & $\begin{array}{l}\Psi(\text { ED) } \\
\text { p (visibility) }\end{array}$ & 175.36 & 1.82 & 1000 & $\begin{array}{l}\Psi(E D) \\
\text { p (visibility) }\end{array}$ & 144.16 & 0.53 & 1000 & $\begin{array}{l}\text { visibility) } \Psi(E D) \\
\text { p (weather + }\end{array}$ & 233.04 & 2.00 \\
\hline & 1500 & $\begin{array}{l}\text { visibility) } \Psi(E D) \\
\text { p (weather + }\end{array}$ & 153.89 & 2.32 & 1500 & $\begin{array}{l}\Psi(\text { ED) } \\
\text { p (visibility) }\end{array}$ & 175.39 & 1.85 & 1500 & $\begin{array}{l}\Psi(\text { ED) } \\
\text { p (visibility) }\end{array}$ & 146.32 & 2.68 & 1500 & $\begin{array}{l}\text { visibility) } \Psi(E D) \\
\text { p (weather + }\end{array}$ & 232.68 & 1.64 \\
\hline & 2000 & $\begin{array}{l}\text { visibility) } \Psi(E D) \\
\text { p (weather + }\end{array}$ & 153.95 & 2.38 & 2000 & $\begin{array}{l}\Psi(E D) \\
\text { p (visibility) }\end{array}$ & 175.49 & 1.95 & 2000 & $\begin{array}{l}\Psi(\mathrm{ED}) \\
\mathrm{p} \text { (visibility) }\end{array}$ & 147.01 & 3.37 & 2000 & $\begin{array}{l}\text { visibility) } \Psi(E D) \\
\text { p (weather + }\end{array}$ & 232.99 & 1.95 \\
\hline & 3000 & $\begin{array}{l}\text { visibility) } \Psi(E D) \\
\text { p (weather + }\end{array}$ & 154.27 & 2.70 & 3000 & $\begin{array}{l}\Psi(\mathrm{ED}) \\
\mathrm{p} \text { (visibility) }\end{array}$ & 175.31 & 1.77 & 3000 & $\begin{array}{l}\Psi(E D) \\
\text { p (visibility) }\end{array}$ & 146.82 & 3.19 & 3000 & $\begin{array}{l}\text { visibility) } \Psi(E D) \\
\text { p (weather + }\end{array}$ & 232.98 & 1.94 \\
\hline & 5000 & $\begin{array}{l}\text { visibility) } \Psi(E D) \\
\text { p (weather + }\end{array}$ & 154.41 & 2.85 & 5000 & $\begin{array}{l}\Psi(E D) \\
\text { p (visibility) }\end{array}$ & 175.46 & 1.92 & 5000 & $\begin{array}{l}\Psi(\mathrm{ED}) \\
\mathrm{p} \text { (visibility) }\end{array}$ & 146.21 & 2.58 & 5000 & $\begin{array}{l}\text { visibility) } \Psi(E D) \\
\text { p (weather + }\end{array}$ & 232.92 & 1.88 \\
\hline & 10000 & visibility) $\Psi(E D)$ & 154.43 & 2.86 & 10000 & $\Psi(\mathrm{ED})$ & 175.41 & 1.87 & 10000 & $\Psi(\mathrm{ED})$ & 146.23 & 2.60 & 10000 & visibility) $\Psi(E D)$ & 231.68 & 0.63 \\
\hline \multirow{9}{*}{ PD } & Null & $\begin{array}{l}\text { p (weather + } \\
\text { visibility) } \Psi(1) \\
\text { p (weather + }\end{array}$ & 152.43 & 0.00 & Null & $\begin{array}{l}\mathrm{p} \text { (visibility) } \\
\Psi(1) \\
\mathrm{p} \text { (visibility) }\end{array}$ & 173.54 & 0.56 & Null & $\begin{array}{l}\mathrm{p} \text { (visibility) } \\
\Psi(1) \\
\mathrm{p} \text { (visibility) }\end{array}$ & 145.56 & 0.00 & Null & $\begin{array}{l}\mathrm{p} \text { (weather + } \\
\text { visibility) }(1) \\
\text { p (weather + }\end{array}$ & 231.04 & 0.00 \\
\hline & 500 & $\begin{array}{l}\text { visibility) } \Psi(\mathrm{PD}) \\
\text { p (weather + }\end{array}$ & 154.21 & 1.78 & 500 & $\begin{array}{l}\Psi(\mathrm{PD}) \\
\mathrm{p} \text { (visibility) }\end{array}$ & 175.17 & 2.18 & 500 & $\begin{array}{l}\Psi(\mathrm{PD}) \\
\mathrm{p} \text { (visibility) }\end{array}$ & 147.01 & 1.46 & 500 & $\begin{array}{l}\text { visibility) } \Psi(\mathrm{PD}) \\
\text { p (weather + }\end{array}$ & 233.03 & 1.99 \\
\hline & 750 & $\begin{array}{l}\text { visibility) } \Psi(\mathrm{PD}) \\
\text { p (weather + }\end{array}$ & 154.39 & 1.95 & 750 & $\begin{array}{l}\Psi(\mathrm{PD}) \\
\mathrm{p} \text { (visibility) }\end{array}$ & 173.04 & 0.06 & 750 & $\begin{array}{l}\Psi(\mathrm{PD}) \\
\mathrm{p} \text { (visibility) }\end{array}$ & 147.30 & 1.74 & 750 & $\begin{array}{l}\text { visibility) } \Psi(P D) \\
\mathrm{p} \text { (weather + }\end{array}$ & 232.69 & 1.65 \\
\hline & 1000 & $\begin{array}{l}\text { visibility) } \Psi(\mathrm{PD}) \\
\text { p (weather + }\end{array}$ & 154.09 & 1.65 & 1000 & $\begin{array}{l}\Psi(\mathrm{PD}) \\
\text { p (visibility) }\end{array}$ & 174.04 & 1.06 & 1000 & $\begin{array}{l}\Psi(\mathrm{PD}) \\
\mathrm{p} \text { (visibility) }\end{array}$ & 147.54 & 1.99 & 1000 & $\begin{array}{l}\text { visibility) } \Psi(\mathrm{PD}) \\
\mathrm{p} \text { (weather + }\end{array}$ & 233.39 & 2.35 \\
\hline & 1500 & $\begin{array}{l}\text { visibility) } \Psi(\mathrm{PD}) \\
\text { p (weather + }\end{array}$ & 152.91 & 0.48 & 1500 & $\begin{array}{l}\Psi(\mathrm{PD}) \\
\mathrm{p} \text { (visibility) }\end{array}$ & 172.98 & 0.00 & 1500 & $\begin{array}{l}\Psi(\mathrm{PD}) \\
\mathrm{p} \text { (visibility) }\end{array}$ & 147.53 & 1.97 & 1500 & $\begin{array}{l}\text { visibility) } \Psi(\mathrm{PD}) \\
\mathrm{p} \text { (weather + }\end{array}$ & 233.04 & 2.00 \\
\hline & 2000 & $\begin{array}{l}\text { visibility) } \Psi(\mathrm{PD}) \\
\text { p (weather + }\end{array}$ & 152.71 & 0.28 & 2000 & $\begin{array}{l}\Psi(\mathrm{PD}) \\
\mathrm{p} \text { (visibility) }\end{array}$ & 173.10 & 0.12 & 2000 & $\begin{array}{l}\Psi(\mathrm{PD}) \\
\mathrm{p} \text { (visibility) }\end{array}$ & 147.55 & 2.00 & 2000 & $\begin{array}{l}\text { visibility) } \Psi(\mathrm{PD}) \\
\mathrm{p} \text { (weather + }\end{array}$ & 232.52 & 1.48 \\
\hline & 3000 & $\begin{array}{l}\text { visibility) } \Psi(\mathrm{PD}) \\
\text { p (weather + }\end{array}$ & 153.32 & 0.89 & 3000 & $\begin{array}{l}\Psi(\mathrm{PD}) \\
\text { p (visibility) }\end{array}$ & 174.65 & 1.67 & 3000 & $\begin{array}{l}\Psi(\mathrm{PD}) \\
\mathrm{p} \text { (visibility) }\end{array}$ & 147.56 & 2.00 & 3000 & $\begin{array}{l}\text { visibility) } \Psi(\mathrm{PD}) \\
\mathrm{p} \text { (weather + }\end{array}$ & 231.96 & 0.92 \\
\hline & 5000 & $\begin{array}{l}\text { visibility) } \Psi(\mathrm{PD}) \\
\text { p (weather + }\end{array}$ & 153.62 & 1.19 & 5000 & $\begin{array}{l}\Psi(\mathrm{PD}) \\
\mathrm{p} \text { (visibility) }\end{array}$ & 174.72 & 1.74 & 5000 & $\begin{array}{l}\Psi(\mathrm{PD}) \\
\mathrm{p} \text { (visibility) }\end{array}$ & 147.41 & 1.86 & 5000 & $\begin{array}{l}\text { visibility) } \Psi(\mathrm{PD}) \\
\mathrm{p} \text { (weather + }\end{array}$ & 231.46 & 0.42 \\
\hline & 10000 & visibility) $\Psi(\mathrm{PD})$ & 153.82 & 1.39 & 10000 & $\Psi(\mathrm{PD})$ & 175.46 & 2.47 & 10000 & $\Psi(\mathrm{PD})$ & 146.94 & 1.38 & 10000 & visibility) $\Psi(\mathrm{PD})$ & 232.47 & 1.43 \\
\hline \multirow{9}{*}{ FC } & Null & $\begin{array}{l}\mathrm{p} \text { (weather + } \\
\text { visibility) } \Psi(1) \\
\text { p (weather + }\end{array}$ & 152.43 & 3.88 & Null & $\begin{array}{l}\mathrm{p} \text { (visibility) } \\
\Psi(1) \\
\mathrm{p} \text { (visibility) }\end{array}$ & 173.54 & 2.41 & Null & $\begin{array}{l}\mathrm{p} \text { (visibility) } \\
\Psi(1) \\
\mathrm{p} \text { (visibility) }\end{array}$ & 145.56 & 0.00 & Null & $\begin{array}{l}\mathrm{p} \text { (weather + } \\
\text { visibility) }{ }^{\prime}(1) \\
\text { p (weather + }\end{array}$ & 231.04 & 0.00 \\
\hline & 500 & $\begin{array}{l}\text { visibility) } \Psi(\mathrm{FC}) \\
\text { p (weather + }\end{array}$ & 148.55 & 0.00 & 500 & $\begin{array}{l}\Psi(\mathrm{FC}) \\
\text { p (visibility) }\end{array}$ & 171.13 & 0.00 & 500 & $\begin{array}{l}\Psi(\mathrm{FC}) \\
\text { p (visibility) }\end{array}$ & 145.76 & 0.21 & 500 & $\begin{array}{l}\text { visibility) } \Psi(\mathrm{FC}) \\
\text { p (weather + }\end{array}$ & 231.49 & 0.44 \\
\hline & 750 & $\begin{array}{l}\text { visibility) } \Psi(F C) \\
\text { p (weather + }\end{array}$ & 150.32 & 1.76 & 750 & $\begin{array}{l}\Psi(\mathrm{FC}) \\
\mathrm{p} \text { (visibility) }\end{array}$ & 171.57 & 0.44 & 750 & $\begin{array}{l}\Psi(\mathrm{FC}) \\
\mathrm{p} \text { (visibility) }\end{array}$ & 145.58 & 0.03 & 750 & $\begin{array}{l}\text { visibility) } \Psi(\mathrm{FC}) \\
\text { p (weather + }\end{array}$ & 232.01 & 0.97 \\
\hline & 1000 & $\begin{array}{l}\text { visibility) } \Psi(\mathrm{FC}) \\
\text { p (weather + }\end{array}$ & 149.82 & 1.27 & 1000 & $\Psi(\mathrm{FC})$ & 172.33 & 1.20 & 1000 & $\begin{array}{l}\Psi(\mathrm{FC}) \\
\mathrm{p} \text { (visibili }\end{array}$ & 145.62 & 0.06 & 1000 & visibility) $\Psi(\mathrm{FC})$ & 232.26 & 1.22 \\
\hline & 1500 & $\begin{array}{l}\text { visibility) } \Psi(\mathrm{FC}) \\
\text { p (weather + }\end{array}$ & 150.08 & 1.53 & 1500 & $\begin{array}{l}\Psi(\mathrm{FC}) \\
\text { p (visibility) }\end{array}$ & 173.21 & 2.08 & 1500 & $\begin{array}{l}\Psi(\mathrm{FC}) \\
\mathrm{p} \text { (visibility) }\end{array}$ & 145.58 & 0.02 & 1500 & $\begin{array}{l}\text { visibility) } \Psi(F C) \\
\text { p (weather + }\end{array}$ & 232.88 & 1.83 \\
\hline & 2000 & $\begin{array}{l}\text { visibility) } \Psi(\mathrm{FC}) \\
\text { p (weather + }\end{array}$ & 150.91 & 2.35 & 2000 & $\begin{array}{l}\Psi(\mathrm{FC}) \\
\text { p (visibility) }\end{array}$ & 173.94 & 2.81 & 2000 & $\begin{array}{l}\Psi(\mathrm{FC}) \\
\text { p (visibility) }\end{array}$ & 146.44 & 0.88 & 2000 & $\begin{array}{l}\text { visibility) } \Psi(\mathrm{FC}) \\
\mathrm{p} \text { (weather + }\end{array}$ & 233.03 & 1.98 \\
\hline & 3000 & $\begin{array}{l}\text { visibility) } \Psi(\mathrm{FC}) \\
\text { p (weather + }\end{array}$ & 152.55 & 4.00 & 3000 & $\begin{array}{l}\Psi(\mathrm{FC}) \\
\mathrm{p} \text { (visibility) }\end{array}$ & 174.82 & 3.69 & 3000 & $\begin{array}{l}\Psi(\mathrm{FC}) \\
\mathrm{p} \text { (visibility) }\end{array}$ & 146.45 & 0.89 & 3000 & $\begin{array}{l}\text { visibility) } \Psi(\mathrm{FC}) \\
\mathrm{p} \text { (weather + }\end{array}$ & 233.04 & 1.99 \\
\hline & 5000 & $\begin{array}{l}\text { visibility) } \Psi(\mathrm{FC}) \\
\text { p (weather + }\end{array}$ & 153.57 & 5.02 & 5000 & $\begin{array}{l}\Psi(\mathrm{FC}) \\
\text { p (visibility) }\end{array}$ & 175.41 & 4.28 & 5000 & $\begin{array}{l}\Psi(\mathrm{FC}) \\
\mathrm{p} \text { (visibility) }\end{array}$ & 146.73 & 1.17 & 5000 & $\begin{array}{l}\text { visibility) } \Psi(\mathrm{FC}) \\
\text { p (weather + }\end{array}$ & 232.91 & 1.87 \\
\hline & 10000 & visibility) $\Psi(\mathrm{FC})$ & 153.98 & 5.42 & 10000 & $\Psi(\mathrm{FC})$ & 175.51 & 4.38 & 10000 & $\Psi(\mathrm{FC})$ & 146.84 & 1.28 & 10000 & visibility) $\Psi(\mathrm{FC})$ & 232.85 & 1.81 \\
\hline
\end{tabular}

